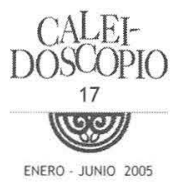

\title{
"Primor con fuerza". Trayectoria existencial de Bernardo de Vargas Machuca
}

BENJAMIN FLORES HERNÁNDEZ

Departamento de Historia/UAA

\begin{abstract}
A parte de otras cosas, que se verán al recorrer los días de su vida en las siguientes páginas, Bernardo de Vargas Machuca fue un afortunado autor de frases, y hasta inspirador para que algún otro creara alguna al referirse a su persona. Así, la más famosa de las que compuso es la que figura al inicio de la Milicia indiana, debajo de su retrato, y la cual muchas veces se ha reproducido como simbólica de la actitud esforzada e inquebrantable suya y de sus compatriotas contemporáneos: "A la espada y el compás/ más, y más, y más, y más". ' Y asimismo es célebre la que sobre el sentido de su refutación a posteriori del padre las Casas puso fray Antonio de Remesal en un libro suyo, de haber pretendido don Bernardo "mostrar las fuerzas de su entendimiento en pelear con el Cid después de muerto". ${ }^{2}$ La que he querido recordar aquí es la que colocó, también como lema y debajo del dibujo de un jinete,
\end{abstract}

1 Bernardo de Vargas Machuca, Milicia y descripción de las Indias, Madrid, Pedro Madrigal, 1599, [16] + $186+[20]$ hh., grabs., El grabado y el lema aparecen después de los preliminares, antes de la h. 1 .

2 Antonio de Remesal, Historia general de las Indias Occidentales, y particular de la gobernación de Chiapa y Guatemala, próls. de Antonio Batres Jáuregui y Manuel Valladares, est. biogr. de Francisco Fernández del Castillo, $2^{a}$. ed., 2 tt., Guatemala, Tipografía Nacional, 1932 (Biblioteca "Goathemala", IV y V), t. II, p. 470. Esta frase de Remesal 
en dos de sus libros sobre equitación: "primor con fuerza". ${ }^{3} \mathrm{Si}$ en tal lugar esas palabras significaban la necesidad de aunar el primor - la destreza, el cuidado, el arte - con una manera fuerte y decidida de hacer las cosas sobre el caballo, aquí he decidido recordarla como epígrafe para esta revisión de la vida del hidalgo de Castilla porque creo resulta exacta definición de su actitud en cada uno de los momentos y circunstancias por los que fue pasando: hacer todo con una conjunción de fortaleza, decisión, rigor, exactitud en el fondo, dentro de una forma cuidadosa, esmerada y suave: "primorosa".

En realidad, no han sido muchos los que, desde que falleciera en 1622, se han acercado a su figura. Prácticamente estuvo olvidado durante los siglos xvI y xvIII, aunque su nombre figuró en el Diccionario de autoridades de la Academia Española (1726-1739). ${ }^{4}$ Antonio María Fabié sacó a luz las Apologías y discursos de las conquistas occidentales en $1879,{ }^{5}$ mismas que hacia 1913 reprodujo

la utilicé para titular un artículo mío acerca de las Apologías...: "'Pelear con el Cid después de muerto'. Las Apologías y discursos de las conquistas occidentales de Bernardo de Vargas Machuca, en controversia con la Brevísima relación de la destrucción de las Indias, de fray Bartolomé de las Casas", en Estudios de historia novohispana, México, Universidad Nacional Autónoma de México, v. 10, 1991, pp. 45-105.

3 Bernardo de Vargas Machuca, Teórica y exercicios de la gineta, primores, secretos y advertencias della, con las señales y enfrenamientos de los cavallos, su curación y beneficio, en Sociedad de Bibliófilos Españoles, Tres libros de jineta de los siglos XVI y XVII, intr.. de C. [esáreol Sanz Egaña, Madrid, Imprenta Aldus, 1951, XLVIII, 270 pp., (Sociedad de Bibliófilos Españoles. Segunda época, XXVI), p. 126. Los dos libros en que se puso este dibujo con su lema fueron este de Teórica y exercicios... -Madrid, Diego Flamenco, 1619- y el Libro de exercicios de la gineta, que es una primera versión de aquél, el cual se publicó en Madrid, por Pedro Madrigal, en el curso de 1600.

4 Real Academia de la Lengua, Diccionario de autoridades. Edición facsímil, 3 vv. Madrid, Editorial Gredos, 1963 (Biblioteca románica hispánica, V. Diccionarios), v. I, p. LXXXXVI.

5 Bernardo de Vargas Machuca, Apologías y discursos de las conquistas occidentales..., apéndice XXII de Antonio María Fabié, Vida y escritos de fray Bartolomé de las Casas, obispo de Chiapas..., 2 tt., Madrid, Imprenta de Miguel Ginesta, 1879, t. II, 
Juan Guixé; ${ }^{6}$ ambas ediciones colocadas al lado de los escritos de fray Bartolomé de las Casas. Victoriano Suárez reeditó la Milicia y descripción de las Indias por $1892^{7}$ y Cesáreo Sanz Egaña publicó la Teórica y exercicios de la gineta en $1951 ;^{8}$ a partir de entonces tales textos de vez en cuando se citan por uno que otro estudioso de alguno de los muchos temas abordados en ellos. Por otra parte, datos para la biografía vargasmachuquiana fueron pacientemente recopilados por Cristóbal Pérez Pastor, ${ }^{9}$ José Toribio Medina ${ }^{10} \mathrm{y}$ sobre todo Enrique Otero D'Costa. ${ }^{11}$ Finalmente, cada uno por nuestro lado, casi al mismo tiempo a mediados de los mil novecientos ochentas, María Luisa Martínez de Salinas y yo dedicamos a este personaje nuestra tesis de doctorado, ${ }^{12}$ hallando ambos en la Biblioteca Universitaria de Salamanca una nueva versión hasta entonces desconocida del manuscrito de las Apologías..., la cual

pp. 409-517. Esta obra se publicó también como los volúmenes LXX y LXXI de la Colección de Documentos Inéditos para la Historia de España; allí, las Apologías... están en el v. LXXI, pp. 201-309.

- Bernardo de Vargas Machuca, Refutación de las Casas (Discursos apológicos en controversia del tratado que escribió Don Fray Bartolomé de las Casas, obispo de Chiapa, en el año 1552. intitulada "Destrucción de las Indias", con Bartolomé de las Casas, Destrucción de las Indias, nota sobre "Las Casas, su vida y obras", de J. Guixé, París-Buenos Aires, Sociedad de Ediciones Louis Michaud, s. f..., 299 pp., (Biblioteca económica de Clásicos castellanos), pp. 141-299.

7 Bernardo de Vargas Machuca, Milicia y descripción de las Indias por el capitán D..., Caballero castellano, natural de la villa de Simancas. Reimpresa fielmente, según la primera edición hecha en Madrid en 1599, con unas "Noticias de la vida y obras del capitán D. Bernardo de Vargas Machuca", 2 vv., Madrid, Librería de Victoriano Suárez, 1892 (Colección de libros raros o curiosos que tratan de América, 8 y 9).

8 Vargas Machuca, Teórica y exercicios...

9 Cristóbal Pérez Pastor, Bibliografia madrileña, o descripción de las obras impresas en Madrid, 3 tt., Madrid, Tipografía de los Huérfanos. Tipografía de la "Revista de Archivos, Bibliotecas y Museos", 1891-1907; sobre todo, t. I, pp. 350 y 351; t. II, pp. 503-510 y t. III, p. 61.

10 José Toribio Medina, Biblioteca hispanoamericana (1491-1810), 7 tt., Santiago de Chile, Fondo Histórico y Bibliográfico José Toribio Mediana, 1958-1962, en particular el t. I, pp. 590-593 y el t. II, p. 314.

11 Enrique Otero D'Costa, "Biográfica disertación sobre el capitán don Bernardo de Vargas Machuca", en Revista de Indias, Madrid, Instituto "Gonzalo Fernández de Oviedo", año XII, enero-marzo de 1952, no, 47, pp. 49-79.

12 La investigación de María Luisa Martínez de Salinas se publicó como Castilla ante el

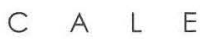


pudo ella editar durante $1993 .{ }^{13}$ En los últimos diez años se han impreso dos nuevas ediciones de la Milicia indiana, una en Caracas ${ }^{14}$ y otra en Valladolid, ${ }^{15}$ con interesantes estudios preliminares de Óscar Rodríguez Ortiz y de Mariano Cuesta Domingo y Fernando López-Ríos Fernández, respectivamente, pero ninguna de ellas aporta nada sustancialmente nuevo acerca de los días y los trabajos de don Bernardo. Y nada más. Yo sigo creyendo en el interés de ahondar en el estudio de este autor, cuyas aportaciones para la interpretación indiana cada vez aprecio más.

Hoy reitero con firmeza que estoy seguro de la importancia de la figura de Vargas Machuca. No nada más por lo que hizo como soldado y como funcionario y por lo que escribió sobre materias muy diversas, acerca de cada una de las cuales realizó aportaciones y expresó juicios que vale la pena tomar en cuenta, sino sobre todo por lo que su personalidad expresa paradigmáticamente: un europeo del tiempo apasionado, ambivalente y descreído del manierismo, un radical español de la contradictoria monarquía de los Felipes, culto y comprometido con

Nuevo Mundo: la trayectoria indiana del gobernador Bernardo de Vargas Machuca, pról. de Demetrio Ramos Pérez, Valladolid, Diputación Provincial de Valladolid, 1991, 247 pp.; para su erudito trabajo, María Luisa Martínez revisó materiales del Archivo General de Indias, secciones Patronato, Indiferente General, Audiencias de Panamá, Santa Fe y Santo Domingo, Contratación y Escribanía de Parte; Archivo Histórico de Protocolos de Madrid, Archivo Histórico Nacional de Madrid, Archivo General Diocesano de Valladolid y Archivo Parroquial de la Iglesia de San Martín de Madrid, así como de las bibliotecas Nacional y del Palacio Real de Madrid y Universitaria de Salamanca. Mi tesis, que en su mayor parte permanece inédita, es Con la espada y con la pluma, el caballo y el compás. Bernardo de Vargas Machuca, un español baquiano de fines del siglo XVI y principios del XVII, México, Universidad Nacional Autónoma de México. Facultad de Filosofía y Letras, 1987, 701 pp.

13 Bernardo de Vargas Machuca, Apologías y discursos de las conquistas occidentales, ed. y est. prel. de María Luisa Martínez de Salinas Alonso, Ávila, Junta de Castilla y León. Consejería de Cultura y Turismo, 1993, 148 pp.

14 Bernardo de Vargas Machuca, Milicia indiana, ed. de Óscar Rodríguez Ortiz, Caracas, Biblioteca Ayacucho, 1994, IX, 126 pp.

15 Bernardo de Vargas Machuca, Milicia y descripción de las Indias, ed. y est. prel. de Mariano Cuesta Domingo y Fernando López-Ríos, Fernández, Valladolid, Seminario Iberoamericano de Descubrimientos y Cartografía. Instituto Interuniversitario de Estudios de Iberoamérica y Portugal. Universidad de Valladolid, 2003, 207 pp. 
las acciones indianas en las que se vio involucrado, y que se americanizó sustancialmente, ejemplificando al baquiano, ese tipo de hispano que, después de una larga permanencia en el nuevo continente, por voluntad propia quiso ser también, y más bien, americano. Ojalá que esta síntesis biográfica contribuya al mejor conocimiento y valoración de su representatividad.

\section{La estirpe de los Vargas Machuca}

Quizás la primera circunstancia que llama la atención del estudioso medianamente enterado de la historia española que se acerca a la persona de un sujeto que se llama Vargas Machuca, sea la de que tales apellidos son, incuestionablemente, de una muy grande prosapia dentro de la tradición ibérica. Si el personaje a cuyo estudio se dedican estas páginas, por su parte, hacia 1600, en la dedicatoria del Libro de exercicios de la gineta al conde Alberto Fúcar, pareciera desconocer o despreciar el abolengo hispano de su nombre, puesto que allí señalaba ante el rico banquero de origen teutón: "la obligación que me corre de descender rectamente de la nación alemana, cuyo nombre es Ferambergue", ${ }^{16}$ lo cierto es que no puede dudarse, de ninguna manera, de que se hallara perfectamente al tanto del legendario génesis de su familia, cuya historia era harto conocida y nunca puesta en duda por sus contemporáneos. Así, por ejemplo, el conde de Villamediana, en la carta que le dirigiera desde Sigüenza a 25 de diciembre de 1618, la cual figura en los preliminares a su Teórica y exercicios de la gineta, hacía referencia a su condición de "hijosdalgo de solar conocido, descendiente del famoso Garcipérez de Vargas, mediante cuyo valor el rey don Fernando ganó a Sevilla, hermano que fue de Diego" Pérez de Vargas, que por su notoria valentía ganó el renombre de Machuca. ${ }^{17}$

16 Citado en José Almirante, Diccionario militar; etimológico, histórico, tecnológico, con dos vocabularios, francés y alemán, Madrid, Imp. y Lit. del Depósito de la Guerra, 1869, XIV, 1218 pp., p. 875.

17 Vargas Machuca, Teórica y ejercicios..., p. 123. 
Si ha de creerse lo que aseguran algunas de las más clásicas -y fabulosas- genealogías de los apellidos castellanos -así el Nobiliario de Francisco Piferrer- nuestro Bernardo el baquiano resulta descendiente directo nada menos que de don Iván -o don Juan- de Vargas, valeroso colaborador del rey Alfonso vi en la conquista de Madrid, allá por el 1083 y, de paso, propietario de aquellos enmilagrados campos que los ángeles bajaron a cultivar para proteger la fervorosa oración de San Isidro Labrador. Y, asimismo, de los hijos y nietos de ese primitivo abuelo: Pedro Ibáñez -o Yáñez-, reconquistador en Toledo, Fernán Pérez, Pedro Fernández, un segundo Fernán Pérez y, por último, otro Pedro Fernández de Vargas, combatiente en la célebre ocasión de las Navas de Tolosa. Este postrero fue padre de los dos más famosos Vargas de la edad media, aquéllos que con tanta reverencia mencionaba Villamediana en la antecitada epístola: García y Diego, el uno activísimo capitán de San Fernando en la toma de la ciudad del Betis, cuyas murallas fue el primero en escalar y el otro, supuesto fundador de la específica línea familiar a la que perteneciera el autor de la Milicia indiana, participante estelar en la batalla de Jerez de 1232. Asegura una antigua tradición que Diego Pérez de Vargas, en el curso de aquella acción de guerra, tras la pérdida de sus armas, logró hacerse de un grueso tronco de oliva que arrancó con sus notables fuerzas, maniobrando con el cual siguió desbaratando a los enemigos, hazaña que vista por su capitán don Álvar Pérez de Castro, le movió a animarle gritándole las rotundas palabras que habría de adoptar él para legar luego a sus sucesores como complemento de su apellido: "iMachuca, Diego, recio, machuca!"18

Este ligero esbozo de la historia de los primitivos Vargas es un resumen de lo apuntado por Francisco Piferrer en su Nobiliario de los reinos y señoríos de España. Contiene las armas y blasones de los reinos, provincias, ciudades, villas y principales pueblos de España, con todos los apellidos que se encuentran en los tratados heráldicos y nobiliarios más autorizados, como son el Libro Becerro de Castilla, Gracia-Dei, Mejía, Barcelos, Mendoza, Argote de Molina, Vitales, Haro, Aponte, Guardiola, Madera, Berni, Moya, Garma, Vargas, Avilés, etc., etc., $6+2$ vv., Madrid, [Diferentes imprentas], 1855-1866, láms. Fundamentalmente, este autor se refiere a ese apellido -para el estudio del cual se basa, sobre todo, en la Nobleza de Extremadura de Alejandro de Silva y Almeida- en el v. I, pp. 144-145 y 150-151, aunque también trae algunas menciones a determinadas ramas de los Vargas-Machuca en el v. II, pp. 268-27l y en el apéndice II, p. 10. Nada menos decía Piferrer que "pocas casas de España pueden contar la serie de 


\section{Nacimiento y primeros años}

No sabemos a qué precisa rama del frondoso árbol de descendientes del forzudo estaqueador de moros perteneció el escritor de la Milicia indiana. Sólo, merced a las sendas epístolas que el capitán Alonso de Carvajal y don Juan de Tassis le escribieron para servir de prólogo a dos de sus libros, así como al texto del testamento que él mismo otorgó poco antes de fallecer, conocemos el nombre de su padre, que fue el capitán don Juan de Vargas Machuca, excombatiente por Alemania y Bohemia, de quien él quedó como primogénito, y la circunstancia de que éste desempeñara, durante muchos años -más de cuarenta y, tal vez, de cincuenta el empleo de "alcaide" del importante alcázar y fortaleza de Simancas; a esa situación paterna debió nuestro autor su

sus preclaras generaciones desde tiempos tan remotos como la casa de Vargas, según se ve por los siguientes apuntes genealógicos". No hace falta decir que lo afirmado en dicho libro ha de tomarse con todas las dudas y reservas que merecen, en general, los tratados de su índole, muchas veces meros compendios, no muy bien hilvanados, de fantasías comúnmente aceptadas; sin embargo, tampoco puede dejar de reconocerse lo hermoso de la fábula anotada y lo representativo de ella dentro de todo el ambiente de romance y novelería que, para los siglos XVI y XVII, poseían determinados episodios de la gesta de la Reconquista. De cualquier modo, tampoco puede decirse que Francisco Piferrer fuera un mero recogedor, sin crítica, de los dichos que escuchaba; así, no prestó mayor crédito a la versión del origen tracio -proveniente de un río Vargus-o romano -creado por el senador Lucio Vargunteyo- del apellido Vargas, el cual más bien supone fundado por "algún caballero godo de los que después se llamaron mixti-árabes o mozárabes". Lo cierto es que, para la época en que escribe don Bernardo de Vargas Machuca, leyendas como la referida estaban fuera de toda duda y no podían menos que influir muy poderosamente en la mente de una persona tan ávida de gloria guerrera como él, y más cuando se pusiera a considerar que esos valerosos soldados de otros tiempos eran precisamente antepasados suyos, sangre de su sangre. Contemporáneo a las obras de Bernardo de Vargas, el Quijote mismo -cuya primera parte quedó impresa en Madrid durante 1605, y en la misma casa que la Milicia indiana- contiene una cita que da fe de lo popular que resultaba por aquellos años la historia de los antepasados de nuestro autor. Allí, en el capítulo Vil de la primera parte, se cuenta cómo recordó don Quijote la acción de Diego Pérez de Vargas en momentos en que él mismo acababa de perder su lanza en la singular batalla que sostuviera con unos gigantes convertidos en molinos por obra de encantamiento; entonces dijo el famoso manchego a Sancho, su escudero, que él tomaría una rama de árbol para sustituir su arma destruida, pues, le 
cuna simanquina. ${ }^{19}$ Por cierto que desde 1539 el referido castillo había empezado a utilizarse como archivo de papeles reales, destino para el cual todavía sirve en la actualidad, hoy como Archivo Histórico. Se sabe que don Juan vivía aún por la época en que Carvajal redactara la mencionada carta, es decir, hacia los años de 1597 o 1598. La madre del biografiado se llamó, por su parte, doña Águeda de Soto. ${ }^{20}$ También

refirió:

-Yo me acuerdo haber leído que un caballero español llamado Diego Pérez de Vargas, habiéndosele en una batalla roto la espada, desgajó de una encina un pesado ramo o tronco, y con él hizo tales cosas aquel día, y machacó tantos moros, que le quedó por sobrenombre Machuca, y así él como sus descendientes se llamaron desde aquel día Vargas y Machuca (Miguel de Cervantes, El ingenioso hidalgo don Quijote de la Mancha, est. prel., ed. y notas por Federico de Onís, 2 vv., México, W. M. Jackson Inc., editores, 1963 (Clásicos Jackson, VI y VII),t. I, p. 73).

Valga tal cita para hacer ver cómo, hasta en la obra cumbre de las letras castellanas, figura el recuerdo de la famosa acción que diera origen al apellido del escritor motivo de este trabajo. Tampoco he podido vencer la tentación de colocar en esta nota, referente a los ilustres creadores de la casa de los Vargas-Machuca, la transcripción de unos populares versos -no por apócrifos menos hermosos- en los cuales aparece el nombre de uno de ellos. En tales rimas se resume la historia legendaria de Sevilla a gusto del espíritu fantaseador de sus habitantes. Estuvieron grabadas en la puerta de Jerez, a la vera del Guadalquivir, muy cerquita de la Torre del Oro, y todavía perduran en la memoria de los sevillanos. Por cierto que también los anota Piferrer. Van así:

Hércules me edificó;

Julio César me cercó

de muros y torres altas;

y el rey santo me ganó

con Garci-Pérez de Vargas.

Por lo demás, no deja de ser curioso que otro importante cronista de la conquista americana, el Inca Garcilaso de la Vega, también descendiera del mismo Garci-Pérez. En un elogio fúnebre dedicado al padre de dicho escritor, el cual recoge su hijo, se aludía a la relación existente entre los dos soldados -Garci-Pérez y Garcilaso padre-, afirmándose la superioridad de las hazañas del segundo (Citado por José Durand, La transformación social del conquistador, 2 vv., México, Porrúa y Obregón, 1953 (México y lo mexicano, 15 y 16), v. I, p. 86).

19 Martínez de Salinas (op. cit., p. 30) precisa que el cargo que desempeñara don Juan en Simancas fue el de pagador de las obras el cual, una vez suprimido el de teniente de alcaide en 1563 y puesto que el de alcaide era en realidad honorífico, venía a ser en realidad "quien cumplía los más altos cometidos en la fortaleza".

20 Vargas Machuca, Milicia..., 1892, v. I, pp. XI y 21 y Teórica y exercicios..., p. 123; así 
hay noticias de un hermano suyo, Bartolomé, igualmente capitán, el cual residía en la isla Margarita por el tiempo en que él tuvo a su cargo la gobernación de ese sitio, y a quien le compró la canoa en la que emprendió el viaje a Cartagena, al iniciar su regreso a España una vez concluido el periodo de su mando allí. ${ }^{21}$

Según reza la portada de la Milicia y confirman repetidas alusiones en el texto de sus libros, nació nuestro autor en la referida villa de Simancas, ubicada en pleno corazón de Castilla la Vieja, a diez kilómetros de Valladolid, sobre el camino a Salamanca. El acontecimiento de su venida al mundo puede ser fijado en el año de 1554 o en el de 1555; ello, partiendo de la suposición de que el pequeño número 43 que se ve a la derecha del retrato suyo existente en la Milicia indiana indica su edad en el momento de grabarse éste, lo que seguramente sucedió durante 1597 o 1598, algo antes de la aparición de ese libro..$^{22}$ La verdad es que su apariencia allí es precisamente la de un hombre cuarentón, en plena madurez de su vida adulta. Por otra parte, las fechas probables de su inicio en el servicio armado, determinadas a partir del número de años que indica nuestro personaje tener de soldado al tiempo de redactar la Milicia, confirman plenamente que debió nacer a mediados de la sexta década del siglo xvi.

Al futuro guerrero, gobernante y escritor le fue impuesto en el bautizo el nombre de Bernardo, de rica tradición germánica, muy común en toda Europa desde la alta edad media, y el cual significa oso fuerte o corazón de oso. Para el siglo xvi existían ya reconocidos oficialmente varios santos y beatos que llevaban ese nombre, incluso algunos de nacionalidad española, tal un San Bernardo de Alcira, moro del siglo

como Otero D (Costa, op cit., p. 78, y su testamento, en Pérez Pastor, op. cit., t. II, pp. 506 y 507. José Toribio Medina (op. cit., t. I, p. 593) dice que el padre de Bernardo, Juan de Vargas, "sirvió 64 años al rey", y que la madre de nuestro biografiado se llamó doña Teresa de Vargas; este último dato se contradice con lo que él hiciera constar en su testamento (loc. cit.), así como con lo que asienta el registro de Bernardo como pasajero en Indias (véase Martínez de Salinas, op. cit., p. 34).

21 Otero D'Costa, op. cit., p. 74; Pérez Pastor, op. cit., t. II, p. 509.

22 Vargas Machuca, Milicia..., 1892, v. I, hoja después de la portadilla. 
XII convertido al cristianismo lo mismo que sus hermanas Zoreida y Zaída, elevadas también a los altares como Santa Engracia y Santa María. Mas, como bien se sabe, el de más trascendencia entre todos los Bernardos santificados era sin duda el doctor Melifluo, el célebre francés reformador del Císter y fundador del monasterio de Clairvaux o Claraval, quien viviera entre 1090 y 1153 , igualmente significativo como predicador y polemista que como místico, el mismo asceta que para librarse de la tentación no vacilara en arrojarse a media noche dentro de un estanque de agua helada. Desde su canonización, en 1174 , la fiesta de este religioso la celebra la Iglesia el día 20 de agosto, aniversario de su muerte. Pero el nombre de pila asignado a nuestro biografiado, más que nada, traía a la memoria de los españoles de su tiempo el recuerdo de otro personaje, hombre legendario cuya historicidad efectiva no acaba de ponerse en claro: Bernardo del Carpio, supuestamente actuante hacia los años iniciales del siglo ix, fabuloso sobrino de Alfonso II, el Casto, de Asturias, a cuyas pretensiones de solicitar ayuda a Carlomagno siempre se opuso, prefiriendo aliarse a los musulmanes de Zaragoza antes que aceptar cualquier intervención transpirenaica en los asuntos internos asturianos. Según la leyenda peninsular, contradictoria de la gala, fue el de Carpio quien, tras de conducir a la victoria a las fuerzas leonesas-zaragozanas en el paso de Roncesvalles, dio muerte con sus propias manos a Roldán, el último en caer allí de los doce Pares de Francia.

No existe ningún dato acerca de los años de infancia del autor de la Teórica y exercicios de la gineta. Ellos seguramente transcurrieron en su misma villa natal, en la cual permaneció comisionado su padre. Resulta indudable que debió realizar algunos estudios formales, puesto que la cultura y conocimientos de que hace gala en todos sus textos indican una formación escolar ciertamente firme. Se ha pensado que tal vez asistió a la Universidad de Valladolid, lo que parece bastante razonable dada la inmediatez de Simancas a esa ciudad castellana, que contaba con una escuela universitaria que, en todo el reino, sólo cedía en prestigio e importancia a las de Salamanca -la cual, en realidad, tampoco le quedaba nada lejos- y Alcalá, y a las que incluso superaba en cuanto a la enseñanza del derecho. Empero, contra la creencia en una significativa incursión escolástica suya se levanta el hecho de los pocos años con que el muchacho contaba al alistase dentro del ejército. 


\section{El aprendizaje de la milicia}

De cualquier modo, haya sido ésta la que fuera, lo cierto es que los tiempos de la primera educación intelectual de Bernardo de Vargas Machuca no duraron mucho. Todavía muy joven, cuando debía andar entre los 13 y los 15 años de edad -es decir, probablemente en el curso de 1568- decidió ingresar en los ejércitos de su patria, formando parte de los cuales pasó a Italia. Allí permaneció, según parece, aproximadamente seis años, incluyendo los meses que asistió a las guerras de Granada, o sea, a las campañas organizadas para sofocar la rebelión de ciertos núcleos de moriscos -musulmanes que habían permanecido en la península después de 1492, bautizados- que, entre 1567 y 1571, se levantaron sobre todo.en la parte sudoriental de España, acatando sucesivamente la jefatura de Abén-Humeya -Fernando de Córdova y de Válor- y de Abén-Aboó -Diego López-. En estas campañas estuvo dentro de una compañía levantada por su padre, en el tercio comandado por Luis de Requesens. ${ }^{23}$ No puede precisarse con exactitud cuáles fueron los servicios que prestara durante el tiempo de su actividad italiana, ni dónde concretamente ni bajo las órdenes de quién tuvieron lugar ellos. Aunque por esos años en la península itálica no ocurrieron lugar hechos de armas de mayor significación, sí puede afirmarse que su experiencia de entonces pesó bastante en el conjunto de su formación castrense, al ampliarle la perspectiva militar que pudo, más tarde, adquirir en América; así, son frecuentes en sus escritos las alusiones comparativas a la forma de combatir en esos dos lugares. Por lo demás, puede asegurarse que durante aquella su larga y a lo que parece no demasiada ajetreada estancia en el territorio italiano fue cuando, más todavía que antes en su tierra natal, llevara a cabo la preparación cultural de la que tantas muestras diera después en los libros que compuso.

A continuación estuvo sirviendo, dice él que desde 1572 hasta 1578, en la armada española; fue entonces, sin lugar a dudas, como

23 Martínez de Salinas, op. cit..., p. 32. 
él mismo afirma, cuando tomó parte en las "guerras de Levante" a las que se refiere el conde de Villamediana en la epístola que se halla al principio de la Teórica y exercicios de la gineta, ${ }^{24}$ interviniendo siempre "en todas las ocasiones que se ofrecieron". ${ }^{25}$ Cabe suponer que la incursión de Vargas Machuca en aquellas aventuras navales emprendidas por su patria tuvo efecto principalmente durante las acciones desarrolladas como consecuencia de la victoria de Lepanto del 7 de octubre de 1571, quizás sobre todo por las épocas - 1573 y 1574 en que los navíos cristianos y turcos, sucesivamente, asaltaban y recuperaban las plazas de Túnez, Bizerta y La Goleta, hasta que finalmente se comprobó imposible el sueño español de consumar la expansión efectiva sobre el norte de África.

\section{La aventura indiana}

Del Oriente pasó Vargas Machuca hasta el Occidente. Dejó las aguas del Mediterráneo para aventurarse en las del Atlántico -el Mar del Norte, se le llamaba entonces- y en las del Pacífico -la Mar del Sur-. Del propio 1578 en que abandonó Levante data la noticia más antigua de su presencia en Indias, pues en la Milicia y descripción consta que durante ese año le sorprendió un terremoto en Santiago de Cuba. ${ }^{26}$ María Luisa Martínez encontró su nombre en las listas de pasajeros a Indias, precisamente en ese año de 1578; allí consta que vino como "criado" del licenciado Antonio Maldonado, oidor en Nueva Galicia. ${ }^{27}$ Seguramente, sólo se halló en las Antillas de paso hacia el continente, y se sabe que, una vez instalado en Nueva España, empezó a ocuparse

24 Vargas Machuca, Teórica y exercicios..., p. 123.

25 Presentación de servicios del capitán don Bernardo de Vargas Machuca. Santa Fe, 14 de mayo de 1590. En "Probanza de servicio de don Bernardo de Vargas". Audiencia de Santa Fe de Bogotá; documentos de 1586 a 1590, algunos de ellos dados en Tunja y en la Trinidad de los Muzos. En ANC, Sección Colonia, fondo Historia civil, 22, ff. 888-972.

26. Vargas Machuca, Milicia ..., 1892, v. II, p. 118.

27 Martínez de Salinas, op. cit., p. 34. 
"en oficios de administración de justicia", ${ }^{28}$ probablemente al lado del licenciado Maldonado, en Guadalajara. No debía tener mucho tiempo aquí cuando Martín Enríquez de Almansa, virrey mexicano desde 1568, quiso aprovechar sus conocimientos marineros y lo envió en búsqueda de "ciertos capitanes del armada que iban sin orden", a los cuales aprehendió; concluida esta diligencia, enseguida se unió con su barco a la flota que, por comisión del mismo representante regio, debió encargarse de perseguir a Francis Drake, el intrépido navegante inglés que, a bordo de un navío ricamente aderezado nombrado el Golden Hind, tras haber cruzado el estrecho de Magallanes a fines de agosto de 1578, se puso a recorrer todo el litoral hispanoamericano de la Mar del Sur, desde Chile hasta California, consumando numerosos robos y atropellos. La noticia de la presencia de los piratas ingleses debió llegar a la capital novohispana a mediados de abril de 1579 , por aviso de Francisco de Zárate, quien se topó con ellos el día 4 de ese mes entre Sonsonete y Tehuantepec, permaneciendo su prisionero durante cuatro días; para entonces, ya el virrey del Perú había enviado al capitán Luis de Toledo en persecución de Drake, quien el primero de marzo anterior había capturado, cerca de Quito, una nave con riquísimo cargamento, la Nuestra Señora de la Concepción, por mal nombre Cacafuego..$^{29}$ Dos años -1579 y 1580, con toda seguridad-dice Vargas Machuca que anduvo embarcado formando parte de la referida flota dispuesta por Enríquez, la cual finalmente se desbarató sin haber

28 Presentación de servicios... Santa Fe, 14 de mayo de 1590, ANC, Sección Colonia, fondo Historia civil, 22, f. 889.

29 Sobre esta expedición desarrollada por sir Francis, de significado no nada más aventurero y de pillaje sino también descubridor y hasta un tanto cuanto científi$\mathrm{co}$, puesto que resultó de circunnavegación, tuve a la vista principalmente lo que sobre ella dice el doctor Enrique Cárdenas de la Peña en su libro Marina mercante, versión completa inédita, México, 1981, VIII, 1043 hh., hh. 400-402. También son muy hermosos los párrafos que le dedica Germán Arciniegas: Biografía del Caribe, 9ª ed., Buenos Aires, Editorial Sudamericana, 1966, 462 pp. (Colección Piragua, 74. Historia), pp. 146 y 147. Drake había salido de su patria con cinco embarcaciones el 13 de diciembre de 1577, y a ella regresó, sólo con su Golden Hind, después de dar toda la vuelta a la esfera terrestre, el 26 de septiembre de 1580 .

$\begin{array}{lllllllllllllll}C & A & L & E & \mid & D & O & S & C & O & P & \mid & O & 19\end{array}$


podido dar caza a los escurridizos corsarios. Luego, todavía siguió él navegando por un tiempo, a su entera costa, sin sueldo, a lo que él dice, dentro de una nueva armada que, también formada con la intención de guardar las costas del Pacífico de las depredaciones del mismo mencionado caballero-ladrón de los mares, se creó por órdenes del virrey del Perú, Francisco de Toledo. Aunque la verdad era que para entonces el prudente Dragón se había retirado ya de la zona, siguiendo su viaje con rumbo al Oeste, hacia las Carolinas y el Extremo Oriente primero, para después completar la circunnavegación por la ruta del cabo de Buena Esperanza. ${ }^{30}$ Indudablemente, fue durante estos años en los que anduvo don Bernardo trabajando en las flotas indiana cuando tuvo oportunidad de conocer buena parte de los muchos lugares americanos en los cuales resulta obvio que alguna vez estuvo, dadas las informaciones que sobre ellos apuntó en sus escritos. Sobre todo fue entonces, con toda probabilidad, cuando debió visitar toda la franja occidental de América: la Nueva Galicia, el sur de Nueva España, Centroamérica, Quito, Perú y, tal vez, hasta Chile.

"Por faltar estas ocasiones", anota Bernardo de Vargas Machuca, aludiendo a la disminución que para la primera mitad de la década de los ochenta se produjo en las acciones marítimas de defensa en contra de la piratería en las que hasta entonces se había hallado comprometido, decidió él aventurarse en las empresas propiamente indianas, ${ }^{31}$ es decir, en las de marcha por el interior del continente que todavía se organizaban con relativa frecuencia, con la esperanza del hallazgo de algún territorio de abundancia parecida a la de alguno de los grandes países ya conquistados.

El paso de nuestro hombre a tierras neogranadinas tuvo lugar, según ciertos indicios, hacia mediados de $1585^{32}$ o probablemente

30 Presentación de servicios..., Santa Fe, 14 de mayo de 1590, ANC, Sección Colonia, fondo Historia civil, 22, f. 889.

31 I6idem.

32 Véase Otero D'Costa, op. cit., pp. 51 y 52. Para tal suposición, este historiador se basa en la declaración del testigo Francisco de Sotomayor en la segunda parte de la "Probanza de servicios de Dn. Bernardo de Vargas Machuca". Audiencia de 
un poco antes. Su arribo a ellas se debió, como él mismo afirmara cuando solicitó de la Audiencia de Santa Fe que se remuneraran sus servicios por marzo de 1590, a la intención de iniciar una expedición en busca del fabuloso reino del Dorado, para lo cual incluso se llegó a poner en comunicación con el adelantado Antonio de la Hoz Berrío, el sobrino político de Gonzalo Jiménez de Quesada que un día, en su Granada, decidió aceptar el legado del pariente de su mujer y cambiar todo el rumbo de su vida europea para acudir a envolverse en la azarosa búsqueda de aquel país cuyo soberano, según se decía, solía empolvarse completamente el cuerpo con oro; como se sabe, en el intento de esta aventura habría de gastar Berrío todo el resto de su existencia. A fin de cuentas, no tuvo lugar esta entrada que pensaba hacer Vargas Machuca y para la cual hasta había llegado a planear las capitulaciones correspondientes, pues el adelantado prefirió realizarla personalmente. ${ }^{33}$

La primera campaña en zonas ahora colombianas en la que participó activamente Bernardo fue bajo las órdenes de Luis Carrillo de Ovando, gobernador de los Muzos y de la Palma, y hubo de desarrollarse en contra de los yariguíes -carares, los llama él, por la región en la que habitaban, en las inmediaciones del río de tal denominación-, unos indios muy belicosos que periódicamente realizaban incursiones sobre los asentamientos cristianos de las márgenes del río Magdalena, en la parte que por entonces se conocía como provincia del Sollo. Esa vez, al estrenarse como guerrero indiano propiamente dicho, actuó como maestre de campo, lo que venía a ser algo así como un segundo del caudillo principal o

Santa Fe de Bogotá; documentos de 1589 a 1592. En ANC, Sección Colonia, fondo Historia civil, 12, ff. 718 a 736. Por agosto de 1592 Sotomayor afirmaba conocer a don Bernardo, en el Nuevo Reino de Granada, "de siete años a esta parte".

33 Presentación de servicios... Santa Fe, 14 de mayo de 1590, ANC, Sección Colonia, fondo Historia civil, 22, f. 889. La primera vez que Berrío intentó la conquista del Dorado fue en 1584; véase Helena Ruiz, "La búsqueda del Eldorado por Guayana", en Anuario de estudios americanos, t. XVI, Sevilla, Escuela de Estudios Hispano-Americanos, 1959 , pp. $1-166$, p. 47. 
jefe de su estado mayor, ${ }^{34}$ mereciendo que su superior calificara su conducta de entonces como de

mucho primor y diligencia, exponiéndose a muchos riesgos y peligros y gobernando la gente de guerra con mucha prudencia, e animando a los soldados para pasar muchos trabajos que en la dicha jornada se pasaron por ser la tierra muy pantanosa e de arcabuco, intratable, despoblada y sin mantenimientos ni comodidad para los poder meter en ella, e siendo muy bien quisto e obedecido de los soldados, e muy diligente e cuidadoso. ${ }^{35}$

Como los expedicionarios en esa entrada no pudieron llegar a trabar contacto con los naturales cimarrones, hubo necesidad de comenzar otra, tocándole al futuro tratadista, ahora, por encargo del propio gobernador del Muzo, comandar el contingente hispano ya con título de capitán general. Esta jornada la efectuó el de Simancas, según dijera. tiempo después a la Real Audiencia de Santa Fe, "con mucho peligro y trabajo de mi persona y gasto de mi hacienda". ${ }^{36}$ Tras múltiples peripecias, habiendo dado con los yariguíes y tenido diversos enfrentamientos con ellos, utilizando varias técnicas de estrategia que hablaban mejor de sus dotes y habilidades de buen militar que de sus escrúpulos humanitarios, finalmente pudo domeñar por completo su resistencia, de modo que, según él mismo declaraba, quedó desde entonces asegurada para los españoles la comunicación y el libre tránsito a través del Magdalena -el Río Grande, le dice-, suspendido prácticamente durante el tiempo de su ocupación por parte de los indígenas. ${ }^{37}$

34 Sobre la estructura jerárquica de una hueste indiana hay algunas notas en Francisco Morales Padrón, Historia del descubrimiento y conquista de América, $3^{a}$. ed., Madrid, Editora Nacional, 1973, 613 pp. (Mundo científico), pp. 223 y 224.

35 Declaración de Luis Carrillo de Ovando, enero de 1589, en "Probanza de servicios...", ANC, Sección Colonia, fondo Historia civil, 12, ff. 718 a 736. Citada en Otero D'Costa, op. cit., p. 52.

36 Presentación de servicios... Santa Fe, 14 de mayo de 1590, ANC, Sección Colonia, fondo Historia civil, 22, f. 889.

37 l6ídem. Carrillo de Ovando decía, en la ya citada declaración ante la Audiencia de Santa Fe que, por su actuación en esta segunda jornada por la zona, había Vargas 
Hubo, a continuación -hacia 1587 ó 1588- una tercera expedición a la que acudió Vargas Machuca por encargo de Carrillo de Ovando. Fue emprendida para sofocar una revuelta de los indios muzos, encabezados por un cacique llamado Guazara. Probablemente fue esta la campaña más larga y más ardua en la que interviniera, y así lo menciona expresamente en varias partes de su libro de las Apologías y discursos, como ejemplo de acción bélica desarrollada contra unos indios levantiscos, taimados y crueles. De este modo contaba su participación en la difícil batida de aquella rebelión, al acudir ante la Audiencia santafeína para solicitar un premio a sus méritos de entonces:

y después de esto habiéndose alzado en la provincia de Muzo un cacique llamado Guazara con mucha suma de indios sus sujetos, el cual habiendo hecho muchos daños se retiró a tierra de guerra, entré yo con cantidad de soldados y habiendo tenido guazavaras con ellos los desbaraté y prendí al dicho cacique y lo mandé ahorcar y reducí a pacíica población sus indios, todo lo cual se hizo a mi costa y estoy muy pobre y necesitado. ${ }^{38}$

Machuca desbaratado a los yariguíes, "de suerte que se entiende que, mediante los dichos castigos e los trabajos e gastos de hacienda e riesgos de su persona, los dichos indios cimarrones están al presente deshechos, y el dicho camino del Río Grande, por la bondad de Dios, se purgó de ellos". (En "Probanza de servicios...", ANC, Sección Colonia, fondo Historia civil, 12, ff. 718 a 736. Citado en Otero D'Costa, op. cit., pp. 52 y 53). En otro testimonio levantado en igual ocasión, Cristóbal de Chirinos expresaba que, en aquella entrada, nuestro hombre, "a cabo de muchos días y muchos trabajos que pasó, dio con los dichos indios salteadores y tuvo con ellos guazábaras y reencuentros donde los desbarató y aprehendió muchos dellos, y hizo justicia conforme a sus delitos" (Ibídem). En cuanto a los curiosos ardides que utilizó durante la campaña estuvieron, por ejemplo, el de incendiar los caneys en que se habían hecho fuertes los carares y el muy ingenioso aunque no demasiado caritativo de ahogar a uno de los niños indígenas que tenía cautivos con sus madres, para evitar que las indias siguieran pellizcando a sus hijuelos y así impedir que éstos, con sus llantos, llamaran la atención del enemigo y le indicaran el sitio en que se hallaban asentados los españoles (16., pp. 53 y 54).

38 Presentación de servicios... Santa Fe, 14 de mayo de 1590, ANC, Sección Colonia, fondo Historia civil, 22, f. 889. 
La justificación de su determinación de mandar dar muerte al jefe de aquellos infieles sublevados la radicaba en el hecho de su canibalismo puesto que, según él, habíale comprobado nada menos que "haber muerto y comido de su propia gente que le seguían más de cuarenta personas de varones y hembras de la más inútil; hallé mucha carne della en cecina, y doy fe que hallé y vi un indio entero asado y envuelto en hojas de bihao y muy liado". ${ }^{39}$

Esto de la antropofagia de los muzos no era invención de Bernardo de Vargas ni mucho menos. Son muchos los testimonios referentes a ella, bien que a veces limitándola a la costumbre de comer la carne de los enemigos caídos en combate. Él, por su parte, en la quinta de sus Apologías..., dedicada a la Nueva Granada, no escatimaba ninguna fuerte expresión de ésas que no pueden menos que poner los pelos de punta cuando rememoraba ciertos macabros hallazgos, seguros indicios de la dieta caníbal de los muzos, descubiertos por él y por sus hombres al tiempo en que se hallaron efectuando la guerra al referido Guazara. Esta era la descripción que allí hacía del grupo de naturales de referencia, fieros y bárbaros por encima de toda ponderación:

\begin{abstract}
En estas provincias los indios son de tal calidad, que por cualquier enojo que hayan recibido se ahorcan, y así mueren muchos por este modo. Aquí usan grandemente de veneno, y con él han muerto mucha gente de la nuestra; era muy ordinario hallar en el tiempo de la guerra cociendo en las ollas de sus casas carne humana de los soldados, y llegando a comer dellas con el hambre, y topar con la mano y pie, y quizás era de su camarada. ${ }^{40}$
\end{abstract}

Para enero de 1589, apenas lograda la sumisión de los muzos y ejecutada la muerte de su cacique principal, el ya capitán Vargas Machuca entendió que era llegado el momento de empezar a sacar beneficios de sus méritos militares, y así solicitó se levantara probanza testimonial de los servicios que hasta entonces llevaba realizados a favor de su majestad. Cristóbal de Chirinos, el gobernador Luis Carrillo de Ovando,

\footnotetext{
39 Vargas Machuca, Refutación..., p. 194.

$40 \quad$ I6., pp. 285 y 286.

41 "Probanza de servicios...", ANC, Sección Colonia, fondo Historia civil, 12, ff. 719 a 728.
} 
Baltasar -no Beltrán, como erróneamente transcribe Otero D'Costade Villarroel y Diego Serrano presentaron declaración dando fe de la verdad de los hechos consumados por el de Simancas. ${ }^{41}$ Luego, para el 14 de mayo del año siguiente, escribió a la Real Audiencia de Santa Fe pidiendo como remuneración, no sólo a sus actividades personales sino también a los del abuelo de su mujer, Lázaro López de Salazar, uno de los primeros conquistadores del Nuevo Reino, que se le hiciera merced del repartimiento de Choconta, vacante a la sazón o, en tanto éste se proveyera, de algún entretenimiento "en oficios de justicia cuales convengan a la calidad de mi persona y v. s. sea servido". ${ }^{42} \mathrm{De}$ concedérsele lo que demandaba, prometía Bernardo no sólo dejar unos pocos indios que tenía encomendados en la Palma, sino también acudir a pacificar a los indígenas que asolaban el Río Grande de la Magdalena, pagando toda la jornada de su bolsa. Inmediatamente a continuación de la carta remitida por Vargas a la Audiencia, aparece en su original la siguiente anotación: "Que vista por su señoría, mandó que se le acuerde a su tiempo. Ante mí Francisco de Hoyos [rúbrical". ${ }^{43}$

Entre 1590 y 1592 tomó parte el capitán Vargas Machuca en otras expediciones encaminadas al sometimiento de grupos neogranadinos levantiscos. Una de ellas la desarrolló en contra de los temibles pijaos, que sobre todo bajo el cacicazgo de un jefe apellidado Dapuc tenían aterrorizada a la ciudad de Altagracia con sus continuos asaltos y desmanes; mediante su actuación, consiguió nuestro hombre aquietar la zona por completo, según él mismo dice. ${ }^{44}$ Es muy posible que esta campaña por tierras de los pijaos, raza que habitaba la margen izquierda del Magdalena, fuera precisamente aquélla ofrecida por el capitán en su carta a la Real Audiencia; lo cierto es que, según afirmación de Francisco

Otero D'Costa, op. cit., p. 56.

42 Presentación de servicios... Santa Fe, 14 de mayo de 1590, ANC, Sección Colonia, fondo Historia civil, 22, f. 889v.

43 Ibídem.

44 Presentación de servicios del capitán don Bernardo de Vargas Machuca. Santa Fe, 16 de julio de 1592. En "Probanza de servicios...", ANC, Sección Colonia, fondo Historia civil, 12, f. 728 . 
de Sotomayor, soldado que entonces lo acompañó, ella la hizo "a su propia costa y misión, con armas y municiones para la dicha guerra, asistiendo él propio en persona". ${ }^{45}$ Quien también se halló militando hacia las mismas fechas por esa zona fue don Bernardino de Mojica Guevara, tío de la segunda esposa de Vargas Machuca y el cual llegaría a ser, por 1609, gobernador de Santa Fe. Parece ser que la entrada de Mojica devino en un rotundo fracaso puesto que, finalmente, según comenta Otero D'Costa en la "Biográfica disertación sobre el capitán don Bernardo de Vargas Machuca", aquel pacífico vecino de Tunja "salióse de aquellas inhóspitas tierras, a paso más que de trote y con el gozo F-de las ilusiones que se había hecho de llegar a ejercer el mando de las riquísimas regiones que supuso habría de conquistar sin mayores problemas-] en fondo de pozo..." ${ }^{46}$ No es fácil saber si anduvieron juntos en esa ocasión quienes por los mismos días o poco después iban a emparentar políticamente, pero tal cosa parecería contradictoria del buen suceso que afirmaba Vargas coronó su lucha contra los pijaos. Por cierto que, para él, estos tales aborígenes resultaban gente tan "brava y caribe" que hasta tenían establecida "carnicería pública de carne humana". ${ }^{47}$ También eran, según su experiencia, grandes hechiceros de modo que, por sus tratos con el demonio, en una ocasión lograron enterarse de la cercanía de los cristianos, al frente de los cuales se aproximaba el futuro autor de la Milicia indiana. Y menos mal que la Providencia se compadeció entonces de los hispanos y quiso acceder a su petición de oscurecer milagrosamente el cielo para que los indígenas no los acabaran de descubrir cuando los conquistadores los iban a atacar en sus poblaciones, que si no, seguramente hubieran hecho con ellos todo género de crueldades. Don Bernardo se enteró de las mágicas adivinaciones del mohan -el brujo de la tribu-, que había tomado la jopa o yopa -"semilla que masca el indio para hablar con el diablo"- con el fin de descubrir los designios y el paradero de los cas- 
tellanos, gracias a una amigable mujer de la tierra perteneciente a un grupo aliado, de nombre Jaincuma, a la que tenían presa los pijaos y a la cual, por lo visto muy agradecido por sus revelaciones, no pudo él luego recordar sino como a una "hermosa moza"; 48 a lo que se ve, el osado expedicionario y sesudo estratega no dejaba de tener también su corazoncito. El castigo que impuso Vargas Machuca al cacique Dapuc -Dapué, lo llama María Luisa Martínez- fue terrible: se le ejecutó por garrote y luego se le empaló. ${ }^{49}$

La segunda de las empresas "pacificadoras" cumplida por Bernardo de Vargas durante los años mencionados ocurrió bajo las órdenes del capitán Alonso Carrillo, enviado por el alcalde de Tunja a reedificar la ciudad de Santiago de las Atalayas, destruida por los indios cusianas quienes, jefaturados por el cacique Cocha, en primero de febrero de 1591 habían asimismo dado muerte al capitán Pedro Daza, fundador y alcalde de la referida población. ${ }^{50}$ Finalmente, también se encontró en el socorro prestado a la ciudad de Medina de las Torres, que asediaban los becos; a lo que dice, esta intervención suya la remató con toda felicidad, lo mismo que todas las anteriores, de modo que "se aseguró todo lo dicho y allanó los dichos indios becos e hice que diesen de paz y obediencia a su majestad, como la dio el cacique Chicome en nombre de toda la provincia, que nunca había sido dada". ${ }^{51}$

Con el propósito de que se le incorporasen los tres últimos empeños bélicos aludidos, el 16 de julio de 1592 el capitán Vargas Machuca requirió de la Audiencia de Santa Fe una ampliación de la probanza de sus hechos compuesta tres años atrás, aduciendo en su escrito la intención, que ya por entonces empezaba a rumiar, de "ocurrir a vuestro real consejo con todo lo susodicho para la gratificación de los dichos mis servicios"; quienes comparecieron para otorgar el nuevo testimonio fueron Cristóbal Xerez, Luis de Castro, Juan de Candia y Francisco

48 Véase Vargas Machuca, Milicia..., 1892, v. II, pp. 82-85. La explicación de lo que era la yopa, en "Declaración de los nombres propios de este libro", I6., v. II, p. 217.

49 Martínez de Salinas, op. cit., p. 57.

50 Presentación de servicios... Santa Fe, 16 de julio de 1592, ANC, Sección Colonia, fondo Historia civil, 12, f. 728, y Otero D'Costa, op. cit., p. 57

51 Ibídem. 
de Sotomayor..$^{52}$ Empero, todavía faltaban unos cuantos años y algún acontecimiento importante de esta su primera etapa de vida americana, para que partiera con rumbo a la península ibérica, a pretender en el Consejo de Indias el premio debido a sus trabajos de esforzado militar deseoso de engrandecimiento de los dominios de su rey.

Quizás quepa considerar que el momento culminante de la actividad conquistadora de Bernardo de Vargas Machuca sobrevino el 26 de junio de 1593 día en el cual, siguiendo los ritos fundacionales que él mismo, con prolija y evocadora minuciosidad enumeraría más tarde en uno de sus libros,,$^{53}$ estableció una nueva ciudad, su ciudad, a orillas de un río al que da el nombre de Iscance -o Iscancé-, en el territorio de los andaquíes, dentro de una comarca en la que se adentrara merced a la ayuda de un cacique indígena, Campona, "que con su gente me salió a recibir y buscar, y me guió y enderezó en todo". ${ }^{54}$ Resulta muy natural el hecho de que quisiera asignar el nombre de su pueblo natal a la nueva población creada por él con tanto cariño y presumiéndole un futuro de grande prosperidad, puesto que se situaba en tierra "muy rica en minas de oro". ${ }^{55}$

La ubicación de la flamante Simancas la indicaba con precisión su fundador, señalándola sobre las márgenes del referido río Iscance, "a dos grados de latitud, altura septentrional", ${ }^{56}$ en tierras habitadas por los referidos andaquíes. Cabe suponer, partiendo de los datos proporcionados por Vargas, que la expresada corriente fluvial, de la cual apunta "que es muy grande y se junta con el Marañón" ${ }^{77}$-designación con la

52 Presentación de servicios... Santa Fe, 16 de julio de 1592, ANC, Sección Colonia, fondo Historia civil, 12, f. 728.

53 En Vargas Machuca, Milicia..., 1892, v. II, pp. 18 a 23. Allí se refiere nuestro autor, entre otras solemnidades y ceremonias relacionadas con el establecimiento de una nueva ciudad, a las que llama de "protestación", "reto", "posesión", "fundación de la iglesia", "elección de cabildo", "juramentos" y publicación del "bando".

54 Vargas Machuca, Refutación..., p. 292. La fecha de la fundación la da el mismo autor en la Milicia..., 1892, v. II, p. 107.

55 Ib., v. II, p. 108

56 Ib., v. II, pp. 107 y 108.

57 Ib., v. II, p. 149. 
cual identifica el actual río de las Amazonas-, corresponde a alguno de los enormes afluentes amazónicos que nacen en la parte sur de los Andes colombianos, a no mucha distancia de la frontera con Ecuador, tal vez el Putumayo -o Iza- o, con mucha mayor probabilidad, el Caquetá o Yupurá. Por otra parte, se sabe que el grupo indígena de los andaquíes vivía en la zona montañosa y selvática situada alrededor de las cabeceras del Magdalena y del Caquetá, en lugares pertenecientes a los actuales departamentos colombianos de Huila -capital Neiva- y Cauca -capital Popayán- y a las intendencias de Caquetá -capital Florencia- y Putumayo -capital Mocoa-. Asimismo, hay noticias de que a la zona del alto Caquetá se le conoció alguna vez con el nombre de Iscance, como se desprende de lo afirmado por Ortiguera en la Jornada del río Marañón, cuando decía que el origen del río Iza se encontraba en "la provincia de Iscanze y Zibundoy y sus comarcas que es en la gobernación de Popayán" ${ }^{58}$ Debe decirse que ninguno de los ríos señalados, cuando menos en su recorrido más caudaloso, atraviesa el paralelo $2 \mathrm{~N}$, lo que sí hacen tres importantes afluentes del Caquetá: el Orteguaza, el Caguán y el Yarí, citados de poniente a oriente. Sin embargo, tampoco es demasiado meridional la parte de dichas corrientes que pasa por la región que puede ser identificada con la del Iscance, toda vez que ella, en ningún caso, bajaría del grado 1 de latitud septentrional. Con base en todo lo anterior, y teniendo ahora a la vista un mapa contemporáneo de Colombia, me inclino a dar por más probable, para la situación de la ciudad establecida en 1593 por el capitán Vargas Machuca, la orilla del Caquetá, en un lugar bastante inmediato a las fuentes de ese río, quizás todavía en territorio del actual departamento de Cauca; en todo caso, no muy distante de Mocoa, cabecera de la comisaría de Putumayo. Si mi suposición es correcta, el error de don Bernardo al determinar la latitud de aquella población no pasaría, cuando mucho, de un grado.

58 Citado en Ladislao Gil Munilla, Descubrimiento del Marañón, pról. de Amando Melón, Sevilla, Escuela de Estudios Hispano-Americanos, 1954, XVI, 389 pp., p. 316 . También véase Juan Friede, Los andakí, 1538-1947. Historia de la aculturación de una tribu selvática, $1^{\mathrm{a}}$. reimpr., México, Fondo de Cultura Económica, 1974, 304 pp. (Sección de obras de Antropología), p. 82, nota 35. 
Por su parte, Juan Friede, en su libro de Los andakí (1538-1947), historia de la aculturación de una tribu selvática, ${ }^{59}$ localiza con toda exactitud a Simancas en la margen izquierda del alto Caquetá, enfrente del pueblo de Santa Rosa hoy existente allí, en sitio muy cercano al comienzo de esa corriente fluvial, no lejos del llamado "Páramo de los Papas", sólo unos cuantos minutos al sur del paralelo 2.

En cuanto al grupo aborigen de los andaquíes, en cuyos dominios estableció el simanquino la villa de referencia, el propio Friede señala con precisión que, hacia finales del siglo XVI, ésta ocupaba

una faja de unos 100 kilómetros de ancho de la alta selva amazónica extendida a lo largo de la cordillera oriental y encerrada entre los ríos Orteguaza, Caquetá y su afluente el Mocoa. Al mismo territorio huían muchos indios oriundos del Alto Magdalena, para resguardarse de la invasión y opresión de los españoles.

La altura de esta región selvática varía entre los 2000 metros en los altos de la Cordillera, y 300 metros sobre el nivel del mar en las orillas de los ríos. Su clima es húmedo y caliente (28 grados), aunque no ardiente como el de la Baja Amazonia. Su terreno es sólido y fértil, abundante en vegetación, frutos naturales y caza. Las copiosas precipitaciones atmosféricas permiten navegar en canoa desde el pie mismo de la Cordillera durante todo el año. ${ }^{60}$

Estos naturales que, según lo cuenta don Bernardo, cuando él los trató acababan apenas de entrar en contacto con los europeos, con los cuales parece ser que no tuvo problemas y cuyo cacique Campona, como ya se dijo, lo encaminó en sus andanzas por la zona, se convirtieron más tarde en el símbolo de los aborígenes belicosos y cimarrones, jamás dispuestos a incorporarse a los sistemas de vida propuestos por la civilización occidental. Hay incluso quien supone que el denominador común de andaquí no se refería a una tribu específica sino que era general para cualquier indígena salvaje y montaraz de la zona selvática del Alto Caquetá, de esos que de repente se abalanzaban sobre los poblados de españoles y de indios de paz sembrando la muerte y la destrucción; algo así, más o menos, como cuando se daba el apellido de chichimecas a todos los bárbaros depredadores que

\footnotetext{
59 I6., mapa 1 (entre las pp. 16 y 17) y p. 45.

60. Ib., pp. 32 y 33
} 
asolaban el norte de la Nueva España. Con estos individuos, Vargas Machuca ensayó una aproximación pacífica hacia el indio, ejecutada con "blandura y buenas obras", convencido de que "la buena obra es una virtud liberal del ánimo", ${ }^{61} \mathrm{y}$ de que, con quienes hasta entonces nunca habían tenido relación con los cristianos esa era la conducta que debía seguirse, dejando la dureza y fuertes castigos para los que, después de haber dado "la paz y obediencia a su majestad" y recibido "el Santo Evangelio y bautismo", se rebelaban provocando "muertes y daños". ${ }^{62}$ Sin embargo, y como para darle la razón a nuestro biografiado en su escasa estima de las cualidades de los indígenas para mantenerse en su lealtad jurada, no mucho después, para el 1600, poco más o menos, bien es verdad que exasperados por el maltrato que les daban los vecinos de la villa establecida en 1593, "que pasan el río y matan o prenden algún indiezuelo, sin saber si es amigo o enemigo" ${ }^{\prime \prime 3}$, los propios andaquíes la destruyeron, al tiempo que no era sino una pequeña población "de siete u ocho vecinos". Por cierto que en la fuente utilizada por Juan Friede para sentar el dato anterior -el número 208 del Boletín de historia y antigüedades de la Academia de Historia Nacional de Bogotá- se daba por fundador de Simancas a Bernardino de Mojica y Guevara, afirmación la cual puede entenderse quizás no en el estricto sentido de que el tal don Bernardino fuera de hecho quien, in situ, procediera al señalamiento y distribución de la ciudad, sino en el de que este personaje, con cuya sobrina habría de contraer matrimonio Vargas Machuca probablemente en fechas muy poco posteriores, fuera quien ordenara a su pariente y subordinado la población de ese lugar, del cual se indica que al tiempo de su creación estaba "a treinta leguas de indios de guerra". El sacerdote carmelita Antonio Vázquez de Espinosa, en su Compendio y descripción de las Indias Occidentales, redactado en los primeros años del XVII, apuntaba que, para entonces, en todo el valle de Neiva existía una gran cantidad de "ganado cimarrón y sin dueño", derivado del que llevara "el gobernador

\footnotetext{
61 Vargas Machuca, Refutación..., p. 292.

62 Ibidem,

63 Cita en Friede, op. cit., p. 45.
}

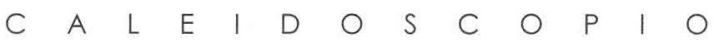


don Bernardo de Vargas Machuca" al dirigirse hacia la zona en la cual habría él de asentar su Simancas; sólo que daba como localización de esa ciudad un lugar "junto adonde estuvo poblada la villa de Neyba", es decir, bastante más al norte que donde yo he supuesto que se encontró ella en realidad, y ya al lado de las aguas del Magdalena. ${ }^{64}$ Según el propio padre Vázquez, la población de la que se ha venido hablando no se despobló sino "después de muchos años", por culpa del "mal gobierno y ruin vecindad de los indios Pixaos, que la hicieron muchos asaltos y daños". ${ }^{65}$

En fin. Haya sido ella en la realidad la que fuera lo cierto es que, contrariando los augurios de su poblador, la historia de la Simancas americana no iba a ser ni muy larga ni muy brillante. Hasta su mismo creador, apenas cinco años después de haberla establecido, resultaba más conocido por su antigua calidad de"vecino de la ciudad de Santa Fe, en el Nuevo Reino de Granada en las Indias Occidentales", ${ }^{66}$ que por la de fundador de aquel poco afortunado asentamiento de avanzada.

Como ha quedado reseñado en los párrafos anteriores, toda su labor guerrera en el continente indiano la desempeñó nuestro hombre, fundamentalmente, en territorios circunvecinos al reino de la Nuevas Granada, a lo largo de la década que va de 1585 a 1595. Esta ajetreada decena de años es el tiempo en el cual adquirió la mayoría de los conocimientos que luego aplicaría en sus escritos sobre tema americano. Fue entonces cuando, asimilando con su natural talento la experiencia directa que le significó la acción militar a través de los diferentes tipos de terreno característicos de aquella región, fue poco a poco convirtiéndose en el diestro baquiano -es decir, profundo cono-

64 Antonio Vázquez de Espinosa, O. Carm., Compendio y descripción de las Indias Occidentales, ed. y est. prel. por B. Velasco Bayón, O. Carm., Madrid, Ediciones Atlas, 1969, XLI, 577 pp., (Biblioteca de Autores Españoles. Desde la formación del lenguaje hasta nuestros días, 231), p. 245.

65. Ibídem.

66 De ese modo se le llamaba en la licencia real que autorizaba la publicación de su libro de la Milicia y descripción de las Indias, dada en Madrid a 2 de octubre de 1598: Vargas Machuca, Milicia..., 1892, v. I, p. 10. 
cedor de los más íntimos detalles del mundo y de la vida de este lado del Atlántico- que llegaría a ser. Como era lo más frecuente, él mismo fue quien se encargó de financiar y organizar todas las entradas que le tocó dirigir por comisión de las autoridades. ${ }^{67}$

En el curso de sus textos, Vargas hace alusión a sus combates en contra de varios grupos diferentes, cuyos nombres ya se mencionaron, todos ellos habitadores de regiones situadas muy cerca de la línea del Ecuador, un poco al norte de ella, en parajes pertenecientes hoy a la república de Colombia. Casi todas sus expediciones, con la única excepción de la que desarrolló en tierra de los andaquíes, las emprendió don Bernardo en represión de naciones antiguamente sometidas y luego levantadas en contra de los españoles. La verdad era que por la época en la que a él le tocó actuar, ese último cuarto del siglo xvi, ya no existía en el horizonte indiano ningún otro gran imperio por conquistar. La mayor ilusión que aún mantenía en tensión a los soldados aventureros era la de llegar al mítico reino del Dorado, en cuya existencia, a pesar de los reveses y dificultades que su búsqueda estaba produciendo, no se quería dejar de creer; el terco capitán Vargas Machuca, empeñado en sostener la efectiva realidad de ese lugar, todavía aseguraba con entusiasmo al redactar su libro de la Milicia indiana: "y de que haya este Dorado y su gran riqueza es cosa cierta y así por toda parte está tan extendida su fama, la cual ha costado gran número de vidas y haciendas, por carecer de su verdadera noticia y camino". ${ }^{68}$

Las ciudades en la cuales parece que vivió más tiempo Vargas Machuca en Indias durante esta su primera estancia por aquí fueron, en alguna época, México, Trinidad de los Muzos, Tunja y Santa Fe

${ }^{67}$ A este respecto resultan muy interesantes las palabras con las cuales él mismo resumía su trayectoria militar, en el prólogo a su Milicia... (I6., v. I, p. 18):

"Obligóme asimismo la escribir el librol el afición que a este arte de la milicia he tenido desde el día que ceñí espada, siguiéndola en Italia, y armadas, y en Indias, donde comencé con el cargo de maestre de campo, y entrando en el de caudillo general, fueron por mi cuenta y riesgo todas las jornadas y conquistas que se me encargaron, que no fueron pocas".

Ib., v. II, p. 198. 
de Bogotá. De recién llegado a América estuvo ocupado en México y Guadalajara con determinados oficios de justicia; luego, ya en tierras del Nuevo Reino, tuvo para ayudarse en su vivir algunas encomiendas de cierta importancia. Mantuvo buenas relaciones con bastantes personajes de significación, y los dos matrimonios que sucesivamente contrajo los hizo con mujeres pertenecientes a las mejores familias neogranadinas. Por su boda en Tunja con doña María de Cerón obtuvo en dote la encomienda de Motabita y tres mil pesos de oro corriente; esta señora, que le dio dos hijos -Juan y Bernardina-, era hija de Rodrigo López Cerón, hijo legítimo a su vez de Lázaro López de Salazar, del cual una información del cabildo tunjano de 16 de mayo de 1589 afirmaba ser uno de los más antiguos conquistadores de la zona y quien, se decía en ese documento,

dende que entró en este reino en compañía del capitán e gobernador Jerónimo Lebrón avrá quarenta y ocho años [-es decir, por 1541 | sirvió a vuestra alteza como bueno y leal vasallo con sus armas y cavallo en la conquista y pacificación deste reino y en todas las ocasiones que se ofrecieron, ansí como contra los tiranos que en su tiempo obo l-probablemente hace referencia aquí a la rebelión de Lope de Aguirre, que se quiso alzar con el dominio de la zona desconociendo a Felipe II, y el cual finalmente murió asesinado en 1561-1 como en todas las demás que fuese en servicio de su alteza y siempre sustentó armas y cavallo en esta ciudad y como tal tuvo oficios de república de regidor, alcalde hordinario e teniente de governador en los quales oficios y cargos sirvió a vuestra alteza en pro e utilidad de esta república $[\ldots]^{69}$

La segunda vez que se casó, después de haber quedado viudo, no debió ser muy posterior. Fue en la villa de Leyra y con doña Juana Mujica -o Mojica- Guevara y Serna, hija de Francisco de la Serna y de Juana de Guevara, hermana esta última del mismo Bernardino de Mojica Guevara, vecino de Tunja y gobernador de Ibague que, con el tiempo, por 1609, llegara a ser también gobernador de Santa Fe, y con quien

69 Testimonio de los servicios de Lázaro López de Salazar. Tunja, 16 de mayo de 1589. En "Probanza de servicio...", ANC, Sección Colonia, fondo Historia civil, 22, f. 971. 
ya se ha dicho que sirvió nuestro hombre en alguna de sus entradas de conquista. La dote que recibió por este nuevo enlace consistió en ocho mil pesos de oro otorgados por el tío de doña Juana, la cual por su parte también le dio al capitán de Castilla un niño y una niña, de nombres Álvaro Félix y María. Por cierto que las dos hijas de don Bernardo, andando el tiempo, habrían de profesar en el convento de la Concepción de la ciudad de Panamá, fundación especial para acoger a las mujeres pertenecientes a las más distinguidas casas indianas. ${ }^{70}$

Debió ser hacia la segunda mitad del penúltimo decenio del XVI, o en todo caso antes de que nuestro hombre se embarcara de vuelta a la península, cuando el padre Juan de Castellanos, el célebre beneficiado de Tunja (1522-1607), le pidió compusiera algunos versos para colocarlos al principio de la segunda parte de sus Elegías de varones ilustres de Indias. Tal solicitud, que indicaba que ya para esas fechas gozaba él de un cierto prestigio como escritor, resultó atendida, de modo que Bernardo le dedicó un soneto el cual, para José Toribio Medina, que en esto se pasaba de rigorista, "en verdad no lo acredita de poeta" ${ }^{71}$ De todos modos, malas o buenas, tales rimas no lograron por entonces el privilegio de la publicación, puesto que la dicha segunda parte de las Elegías de Castellanos, con todos sus versos laudatorios previos, no vio la luz hasta más de dos siglos y medio después, cuando por 1847 apareció en el tomo 4 de la Biblioteca de Autores Españoles editada por Buenaventura Carlos Aribau. En mi opinión, si no extraordinarias, ni mucho menos, no dejaban de ser interesantes las líneas aquellas pergeñadas por quien a la sazón era todavía un autor inédito; en ellas cumplía con suficiente dignidad y hasta con alguna pequeña dosis de ingenio con su exclusivo propósito de quedar bien con su convecino el historiador sevillano-tunjano, quien tampoco era, que se diga, persona particularmente favorecida por los dones de Calíope. Mejor sea juez el lector de las problemáticas calidades literarias del poemilla de

\footnotetext{
70 Estos datos acerca de los matrimonios y la descendencia de Vargas Machuca están tomados del testamento que otorgó poco antes de morir, en 1622. En Otero D'Costa, op. cit., p. 78 y en Pérez Pastor, op. cit., t. II, p. 507.

71 Medina, op. cit., t. I, pp. 592 y 593.
} 
referencia, que por lo demás se limitaba a augurar buena suerte a una obra puesta bajo la protección del rey Felipe II y dedicada a rememorar las gestas americanas de los castellanos. Iba así:

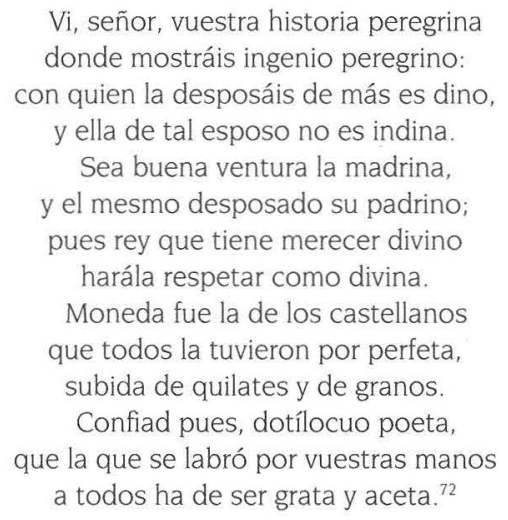

En la corte: pretensiones y escritos

A mediados de 1595 fue cuando Bernardo, satisfecho con la labor guerrera que había llevado a cabo a lo largo de dos decenios en aguas y tierras americanas y considerando que, en justicia, podía aspirar a ser recompensado por ella, se decidió a volver a su patria para solicitar ante el rey alguna gracia en pago a su actividad. Así, pues, lió sus pertenencias, arregló todos los asuntos pendientes y emprendió el viaje a la península ibérica. Es de suponer que había tenido buen cuidado de ir haciendo los ahorros necesarios para que, cuando llegara la hora oportuna, pudiera dignamente ocurrir ante su majestad; él mismo, luego, en su Milicia indiana, recomendaría al soldado americano hiciera "el gasto de tal manera que le quede con que [...] halle un pedazo

72 En Juan de Castellanos, Elegías de varones ilustres de Indias, $3^{a}$. ed., Madrid, M. Rivadeneyra, 1874, $567 \mathrm{pp}$. (Biblioteca de autores españoles, desde la formación del lenguaje hasta nuestros días, ordenada por D. Buenaventura Carlos Aribau, 4), p. 180. 
de pan que comer y con que poder venir ante su príncipe a pedirle mercedes justas $[\ldots]^{\prime 73}$

En realidad, desde que por 1592 solicitara de la Audiencia de Santa Fe se pusiera al día la probanza de sus méritos, había manifestado la intención de presentarse en la corte madrileña, a ver cuál era el pago que en ella se quería dar a su devoción patria. En el curso de las informaciones hechas con este motivo, Cristóbal Xerez, antiguo subordinado suyo, afirmó contundentemente que, según su parecer, el capitán Vargas Machuca era

dino y merecedor de que su Majestad (siendo servido) le haga merced, ansí en encomendar indios, como en ocuparle en cargos y oficios de gobierno y otras cosas de calidad, tocante al real servicio; porque de todo él es digno y merecedor idóneo y suficiente, por ser hombre de muy buen entendimiento, muy discreto y de autoridad, y concurrir en él todas las calidades necesarias a los dichos cargos y oficios. ${ }^{74}$

Embarcado en la flota de julio de 1595, para los últimos meses de ese año ya se encontraba en la villa del oso y del madroño, "catarriberas" frecuentando las antesalas reales en espera de que sus aspiraciones merecieran atención por parte de la superioridad. Pero pasaba el tiempo y, a pesar de todas sus indudables argucias para introducirse cerca de quien le pudiera valer, no veía el valeroso caudillo que se le hiciera el menor caso. Existe constancia de varias peticiones suyas para diversos cargos, como los de gobernador de Cumaná o de Popayán, así como para que se le concediera un hábito dentro de la orden de Santiago. ${ }^{75}$ Cansado de esperar, ante "tanta calamidad de tres años de pretensiones" como ya llevaba, fue que comenzó a redactar su libro de la Milicia indiana. ${ }^{76}$ Con esta tarea, pensaba, no sólo encontraría un pasatiempo mientras continuaba con los abu-

73 Vargas Machuca, Milicia..., 1892, v. I, p. 69.

74 Otero D'Costa, op. cit., p. 61. En cuanto al nombre del testigo debo decir que, en el original de las diligencias (en "Probanza de servicios...", ANC, Sección Colonia, fondo Historia civil, 12, ff. 718 a 736), donde Otero D'Costa ve "Cristóbal Pérez yo leo "Cristóbal Xerez".

75 Martínez de Salinas, op. cit., pp. 75 y 76.

76 Vargas Machuca, Milicia..., 1892, prólogo, v. I, p. 18. 
rridos trámites burocráticos encaminados a la consecución de sus empeños, y eso escribiendo sobre una materia que le fascinaba, con un trabajo que representaba la puesta en orden de sus experiencias de muchos años sino que también, de paso, una vez concluida, indudablemente se vería aumentado su prestigio de profundo conocedor de los temas americanos.

Encontrándose allí, en la corte madrileña de los últimos tiempos de Felipe II y los primeros de Felipe III, Vargas Machuca intentó -y consiguió- relacionarse con algunas personas influyentes. Es posible que, para tal cosa, le fuera de utilidad su condición de hijo del antiguo empleado de Simancas, que era una importante fortaleza real; sin embargo, atendiendo a las repetidas exclamaciones que se encuentran a lo largo de toda su óbra referentes a la necesidad que tenía el indiano de dinero en España, puede tenerse por cierto que la mayor parte de lo que allí consiguió lo obtuvo a base de dádivas y de regalos oportunamente repartidos. Por lo demás, su condición de hombre culto, que había sabido asumir con inteligencia una enorme experiencia militar, lo hizo hallar buena acogida dentro del círculo de letrados cortesanos que jefaturaba el erudito manchego Luis Tribaldos de Toledo. Quizás su introducción en dicho ambiento la debiera a una previa relación, por parte de su familia, con la distinguida casa de los Tassis cuya cabeza, don Juan de Tassis y Acuña, era entonces correo mayor de Castilla; lo cierto es que el hijo de éste, llamado también don Juan, que por entonces no había cumplido los veinte años -puesto que había nacido durante 1582-, fue siempre muy buen amigo de Bernardo: le dedicó uno de los sonetos que aparecen al principio de la Milicia y luego, en 1618, le dirigió la epístola que se puso como prólogo a la Teórica y exercicios de la gineta y cuyos apuntamientos sobre la vida de nuestro soldado y escritor tanto he aprovechado aquí. Este Juan de Tassis y Peralta, el cual en 1607 heredaría el título de conde de Villamediana que por 1603 se concediera a su padre en premio a sus servicios como embajador en Londres y en París, por los años de esa estancia madrileña de Vargas Machuca era pupilo de Tribaldos de Toledo.

De todas formas, atendiendo a algunas expresiones que aparecen a través de su obra, debe decirse que a pesar de lo significativo de varias de las personas con quienes el capitán mantuviera buena relación en España, las cosas allíno le resultaron nunca tan bien como él 
hubiera querido. Sabedor por experiencia propia de las dificultades que se ofrecían a los indianos allí, en sus Apologías y discursos encarecería mucho a sus compatriotas que lo pensaran detenidamente antes de embarcarse de regreso hacia el solar patrio, pues consideraba "bien poco" el provecho de ello y "los riesgos y daños muchos". ${ }^{77}$

Y eso que, aparte de las mencionadas, por la misma época don Bernardo entabló también conocimiento con otras personalidades de relieve, bajo cuyo amparo siguió llevando a cabo sus gestiones para obtener mercedes en la corte. Luego, cuando se trató de la edición del par de obras que por entonces llevara al impresor, le pareció oportuno dedicarlas a dos hombres muy importantes en el ambiente palaciego -don Pablo de Laguna, presidente del Consejo de Indias y el conde Alberto Fugger o Fúcar, castellanizado el apellido, riquísimo banquero perteneciente a la conocida familia originaria de Augsburgo, cuyos dos miembros más representativos fueran sucesivamente Jacobo el Rico (1459-1525) y Antón (1493 1560), a quienes tantos favores debió Carlos $\mathrm{V}^{78}$ - con la esperanza de que, contando con buenos padrinos, alcanzaran sus escritos toda la buena fortuna que seguramente él esperaba de ellos.

Los dos tratados que por entonces, durante su estadía española del cambio de siglo, llevó Bernardo a las prensas -la Milicia y descripción de las Indias y el Libro de exercicios de la gineta- salieron a la luz pública durante 1599 y 1600, respectivamente, ambos editados en Madrid, en casa de Pedro Madrigal. Esta imprenta era una de las más importantes que existían a la sazón en la villa y corte; en los Apuntes para una biblioteca científica española del siglo XVI de Felipe Picatoste, cuyos datos son los que ahora tengo a la mano, se mencionan nada menos que trece libros hechos allí, entre aquellos relacionados con temas científicos, que son los que interesan a dicho autor, por entre los años que van de 1586 a

77 Vargas Machuca, Refutación..., p. 295.

78 En 6 de julio de 1600 don Bernardo firmó en Madrid una obligación en la cual asentaba deber a Marcos Fúcar y hermanos cien escudos de oro, a 400 maravedíes cada uno, que le habían prestado y los cuales se comprometía a devolver a fines del mismo año: Pérez Pastor, op. cit., t. II, pp. 504 y 505. 
1603. ${ }^{79}$ Se sabe también que durante 1599 Vargas Machuca presentó igualmente ante el Consejo de Indias otro escrito que contaba con el rubro de Discurso sobre la pacificación y allanamiento de los indios de Chile en el cual, mostrándose contrario al proyecto de despoblar la región chilena, se comprometía con las autoridades españolas a someter él mismo a los indomables araucanos, con el auxilio de solos cuatrocientos hombres de armas que habrían de ponerse bajo su mando, respondiendo con su propia cabeza del éxito de la empresa. Como consecuencia de este último memorial, su nombre figuró entre los propuestos para comandar la expedición que iría a Chile, aunque a la postre no quedó entre los cuatro capitanes elegidos para esa ocasión. ${ }^{80}$

\section{Alcalde mayor de Portobelo}

Indudablemente, la salida pública de sus textos sirvió para asentar, ante todo el mundo, la realidad de los merecimientos del capitán indiano. Especialmente la Milicia..., en la que con tanta claridad y erudición expresaba toda una teoría militar de las guerras americanas que no podía estar basada sino en muchos años de experiencia directa de ellas, debió contribuir grandemente a que, por fin, en las altas esferas oficiales se fijaran en él para satisfacerlo, cuando menos, en algunas de sus pretensiones. Y así, pues, una vez escuchadas sus solicitudes y ya con su nombramiento de alcalde mayor para Portobelo, el cual se le expidió en Zamora el 6 de febrero de $1602^{81}$, emprendió la vuelta hacia el nuevo continente. Tal cosa debió ocurrir, aproximadamente, a medidos del mismo año de 1602, cuando ya la corte hispana, por

Véase Felipe Picatoste y Rodríguez, Apuntes para una biblioteca científica española del siglo XVI. Estudios biográficos y bibliográficos de ciencias exactas, físicas y naturales y sus inmediatas aplicaciones en dicho siglo, Madrid, Imprenta y fundición de Manuel Tello, 1881, VIII, 416 pp., p. 396. Poco después, esa imprenta la adquirió Juan de la Cuesta quien allí publicó la primera parte de Don Quijote, en 1605. 
cierto, se había trasladado a Valladolid, donde residió desde 1600 hasta 1606.

Es muy probable que haya sido entonces, al empezar el viaje de vuelta, cuando pasó por París ciudad en la cual, según comenta en la quinta de sus Apologías y discursos..., se dio cuenta de cómo eran utilizadas y exageradas las afirmaciones antiespañolas hechas por fray Bartolomé de las Casas en la Brevísima relación de la destrucción de las Indias, con base en las cuales él vio allí "pintados lienzos" y compuesta multitud de estampas y relaciones. ${ }^{82}$ Tal situación lo indignó, como era natural en un hombre hispano que había convertido en trabajo central de su acción en la vida, precisamente, la participación en la empresa de expansión llevada a cabo por su patria en América. Confiesa él mismo que uno de los motivos que lo llevaron a componer un libro en su refutación fue la circunstancia de ver que, como consecuencia de la divulgación de la obra lascasasiana, "no hay naciones extranjeras que no tengan a los españoles por la gente más cruel que tiene el mundo". ${ }^{83}$

Como era de esperarse, la nueva permanencia indiana de Vargas Machuca, la cual iba a abarcar, aproximadamente, algo menos de tres lustros, tuvo un sentido bastante diferente al de la anterior. Rondando la cincuentena en el momento de pisar de nuevo América, no era cosa de volver otra vez a pretender entrar, personalmente, en alguna conquista; él mismo, al hablar de la edad recomendada para el caudillo en ella, había expresado que no convenía fuera demasiado viejo al intentarla. Por lo demás, su Milicia indiana alcanzó pronto una notable popularidad en estas tierras, con la consecuencia de que a él se le tuviera en todas partes por un experto en los asuntos locales y que continuamente se acudiera a su persona para la resolución de dudas sobre temas específicos. De este modo, ahora, su actividad resultó fundamentalmente la de un especialista cuyos conocimientos fueron aprovechados en labores gubernativas y de consulta. Muy típico de esta nueva situación suya resulta el hecho de que, en 1606, Juan López de

82 Vargas Machuca, Refutación..., p. 285.

83 Ibídem.

C A L L E I 
Sequeira, gobernador de Veragua, pensara en él para que lo ayudara a responder a los diferentes cargos que se le imputaban por su conducta en la conquista de Guaymijcoclé, pues consideraba a don Bernardo "como persona que tanto conocimiento, práctica y espiriencia alcanza dellas [-las conquistas-], como quien para las hacer ha dado escuela e instrucciones en el libro intitulado Milicia indiana". ${ }^{84}$

Asimismo, todo indica que fue por esos mismos primeros años de su segunda residencia en Indias, mientras se hallaba en la ciudad ístmica, cuando redactó la mayor parte de sus Apologías y discursos de las conquistas occidentales, aunque quizás ya tenía compuesta alguna fracción de ellas desde épocas anteriores y aunque todavía más adelante habría de revisarlas, de corregirlas y hasta de hacerles determinados agregados importantes.

Por comisión regia, al capitán Bernardo de Vargas le tocó desempeñar, durante un lapso de seis años -1602 a 1608-, la alcaldía mayor de San Felipe de Portobelo -Puerto Bello, según se escribía en la época-, la cual acababa de ser fundada por don Francisco Valverde y Mercado, en 20 de marzo de 1597. Dicho empleo gozaba de un salario anual de mil doscientos ducados; en lo militar quedaba sujeto al gobernador y capitán general de Tierra Firme y en lo civil a la Audiencia de Panamá. ${ }^{85}$ La localidad de referencia, ubicada en la costa atlántica de la Tierra Firme, se había poblado con los habitantes de Nombre de Dios, que se trasladaron a ella debido a su mejor clima, unos pocos meses después de que Francis Drake, como última gracia antes de morirse de fiebre enfrente de sus playas el 28 de enero de 1596, hubiera pegado fuego a Nombre de Dios y Santa Marta. En Portobelo tenía lugar el desembarque de los pasajeros y de las mercancías que se dirigían hacia el Perú después de tocar en Cartagena y, viceversa, la partida de los navíos que retornaban a España. Por su magnífica situación, esa ciudad estaba destinada a convertirse, en poco tiempo, en una localidad importantísima.

Bernardo de Vargas Machuca, "Apologías y discursos de las conquistas occidentales...", manuscrito, $7+200+1$ ff., en la Biblioteca Universitaria, Salamanca, ms. 2010, f. 179v. Este Parecer lo firmó en Panamá el 26 de abril de 1606 (I6., f. 197). 
Don Bernardo, que recibiera la designación desde que se encontraba en España, debió empezar a ejercer sus funciones de alcalde mayor apenas arribado a su destino. Lo que se sabe de cierto es que, además de gobernar la población, se ocupó también, por encargo real, de atender a su fortificación, contando para ello con la ayuda de la "gente de guerra" local. ${ }^{86}$ Y así, pues, se dedicó con ahínco a continuar las obras de los castillos de San Lorenzo, en la desembocadura del río Chagres y de San Felipe, Santiago de la Gloria y San Cristóbal en la entrada del propio Portobelo, las cuales se habían iniciado algunos años antes de su venida, todavía en tiempos de Felipe II, durante la gestión de su antecesor en el cargo Miguel Ruiz Elduhayen ${ }^{87}$ a partir de proyectos elaborados por el conocido arquitecto Juan Bautista Antonelli, perteneciente a una famosa familia de ingenieros y constructores originarios de la Romagna, en Italia. En febrero de 1601, el año anterior a su llegada, había ocurrido el asalto a la población por parte del pirata inglés William Parker, que fue el primero de los muchos que la atacaron a lo largo de los siglos xvi y xvil. Aunque la documentación revisada por María Luisa Martínez da cuenta de las dificultades y conflictos que tuvo Vargas Machuca durante su estadía en Portobelo, la verdad es que la Corona no debió ver mal en general su desempeño allí, puesto que aceptó su petición

86 En el manuscrito de las Apologías... que se conserva en la Biblioteca del Palacio Real de Madrid (Bernardo de Vargas Machuca, "Apologías y discursos de las conquistas occidentales...", manuscrito, 8 + 171 ff., en la Biblioteca del Real Palacio de Madrid, ms. 2965), f. 1, en la dirección de la carta del fiscal de Panamá Zoyl Díez Flores se halla tachada la siguiente frase, referente a la situación de Vargas Machuca: "alcalde mayor de la ciudad de San Felipe de Puerto Bello del mismo reino [de Tierra Firme] y comisario de las fábricas y fortificaciones, de orden del rey nuestro señor y costo de la gente de guerra". Indudablemente, tales eran los cargos de don Bernardo cuando Díez Flores le escribió. Lo que debió suceder fue que, alguna de las veces que arregló ese manuscrito para su eventual publicación, decidió que en el libro a editarse sólo se aludiera a su nueva situación de gobernador; por ello mismo, igualmente quitó la palabra "capitán" que aparecía allí antes de su nombre para colocar, en su lugar, la indicativa de su nuevo cargo. El conde de Villamediana, en la carta que existe en el libro de Teórica y exercicios... (op, cit., pp. 123 y 124), se refería a "los castillos de Puertobelo y río de Chagre, que fabricó por orden de su Majestad tan importantes a su real servicio".

Otero D'Costa, op. cit., p. 66.

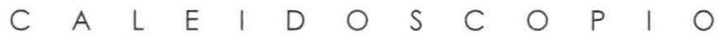


de traslado a otro destino y lo mandó Margarita, lo que en realidad significaba un ascenso para él. ${ }^{88}$

\section{La gobernación de Margarita}

Tras mantenerse en Portobelo los seis años estipulados en el nombramiento, pasó el simanquino a ejercer el cargo de gobernador de la isla Margarita. Aunque el título de su designación databa del 3 de febrero de 1608, parece que el quinquenio que habría de permanecer en ese empleo no debía empezar a contar hasta principios del año siguiente. Arribó a su destino el 2 de enero de 1609, tomó posesión el 21 de ese mismo mes y el 10 de junio fechaba ya una carta que remitía a su majestad, referente a sus impresiones acerca de la defensa de la plaza. ${ }^{89}$ En esta isla, situada en el mar Caribe, enfrente de la costa de Venezuela, célebre por sus madreperlas desde los tiempos inmediatamente posteriores a los descubrimientos colombinos, permaneció don Bernardo por espacio de siete u ocho años, al cabo de los cuales llegó a quererla entrañablemente. Su traslado para allá le significó una buena mejora, pues siempre representaba más el mando de una provincia -la cual, gracias a sus perlas, tenía una cierta importancia económica- que el de una sola ciudad, por más que esta fuera tan significativa como Portobelo. En cuanto a su salario, al pasar al nuevo destino se le incrementó en trescientos ducados anuales, llegando a los mil quinientos. ${ }^{90}$

La labor de Vargas Machuca como gobernante de la isla fue empeñosa y, cuando menos en opinión de sus amigos, notable. De ella comentaba el conde de Villamediana en su multicitada carta del día de Navidad de 1618:

Pero no es de pasar en silencio el gobierno de la isla Margarita donde, como capitán general, fue temido de infieles y respetado de los naturales por lo mucho que trabajó en

Sobre su actuación en Portobelo, ver Martínez de Salinas, op. cit., pp. 81-114.

I6., p. 152

Otero D'Costa, op. cit., p. 72. 
su beneficio, fortificando la ciudad a su costa con un eminente castillo y otros reparos, gastando con liberal mano su hacienda en la defensa, policía y adorno, con cuanto una ciudad para ser inexpugnable y nombrada en lo divino y humano ha menester. ${ }^{91}$

Durante el tiempo que permaneció allí, el de Castilla la Vieja se dedicó a atender con empeño a los principales problemas que aquejaban a la gobernación. Apenas llegado elaboró un informe acerca de las medidas que consideraba más oportunas para mejorar la defensa del lugar, para lo cual pensaba entonces no hacía falta levantar un nuevo fuerte en Pampatar, sino más bien mejorar la artillería de las construcciones ya existentes y mantener en ellas una vigilancia permanente que avisara de las invasiones extranjeras mediante oportunos cañonazos que llamaran al arma a los ciudadanos. ${ }^{92}$ Según su parecer, lo más necesario para la cabal guarda de la isla era la existencia de un buen arsenal de armas y pertrechos bélicos, los cuales pedía se le suministraran oportunamente; por lo demás, tampoco descuidó el arreglo de las defensas ya existentes, como el castillo de San Bernardo, en el cual llevó a cabo importantes obras de reparación, ni la erección de algunas nuevas, tal un rebellón de mampostería en la puerta de la capital. ${ }^{93}$ Atento siempre a vigilar los intereses de su majestad, el 13 de julio de 1613 puso una carta a las autoridades de las cuales él dependía dándoles cuenta de la cercana presencia de algunos grupos de ingleses que, contando con la ayuda de los caribes, habían empezado a cultivar tabaco; poco después complementó su información con la indicación de que también había súbditos de Su Majestad Británica en la Guayana y en la Trinidad, donde incluso estaban formando poblados. No le atemorizaba a él mucho esa vecindad, pero sí le incomodaba. Para expulsar a los intrusos pedía tan sólo unos cuarenta hombres de guerra con los

91 En Vargas Machuca, Teórica y exercicios..., p. 124. Un estudio amplio acerca de las diversas facetas de la actividad de don Bernardo en la isla Margarita, en Martínez de Salinas, op. cit., pp. 127-224.

92 Antonia F. Heredia Herrera, "Las fortificaciones de la isla Margarita en los siglos XVI, XVII y XVIII", en Anuario de estudios americanos, t. XV, Sevilla, Escuela de Estudios Hispano-Americanos, 1958, pp. 429-514, pp. 457 y 458.

93 Ibidem. 
cuales, unidos a los cincuenta experimentados baquianos con los que él contaba entre su gente, no dudaba en despejar las inmediaciones de su comarca de los molestos herejes. ${ }^{94}$

Por otra parte, también se interesó en promover el desarrollo de la principal fuente de ingresos de la isla, la perlería, esforzándose mucho en evitar las infracciones de los pescadores a las ordenanzas que vedaban la explotación de los criaderos que todavía no estuvieran completamente en su punto. ${ }^{95}$ Tanto se apasionó por el tema de las joyas que daban nombre y fama a su gobernación, que con el tiempo llegó hasta a esbozar una teoría -una "filosofía-, dice él- acerca de todas las circunstancias que debían concurrir para que tuviere efecto la completa "generación" de la "semilla" de las ostras, las cuales resumía en cuatro "causas": profundidad del mar entre cuatro y doce brazos, existencia de rocío y de alguna lluvia, "comederos" adecuados para las madreperlas y, por último, una determinada latitud que hiciera que la zona fuera "caliente y dentro de las cárceles del sol, en cuya altura hieren sus rayos perpendicularmente dos veces al año". ${ }^{96}$ La verdad es que, a pesar de tales ideas suyas acerca del origen de las perlas y de la manera de aumentar su recolección, el producto perlífero de la Margarita, muy disminuido desde antes de que él llegara a la isla, no pudo nunca recuperarse. ${ }^{97}$

Tan bien llegó a conocer don Bernardo las interioridades de este territorio bajo su mando y las de sus pobladores -margariteños o guaiqueríes-, y tan identificado llegó a sentirse con los problemas y peculiaridades del lugar que le dedicó todo uno de los seis "discursos" en que dividió su libro de las Apologías..., precisamente el último, mismo que redactó después de que, anteriormente, ya había dado por concluido ese escrito. En dichas páginas se expresaba de los aborígenes isleños con palabras que indican el buen aprecio que llegó a sentir por ellos, calificándolos nada menos que de "los indios más señalados

\footnotetext{
94 Ruiz, op. cit., pp. 82 y 83.

95 Véase Heredia, op. cit., p. 456.

96 Vargas Machuca, Apologías..., Salamanca, ff. 177-178.

97 Martínez de Salinas, op. cit., pp. 163 y ss.
} 
y de estima y privilegiados"98 de toda América. Comentaba que, de haber sido iguales en lealtad a su palabra de servir al rey de España y en buena disposición para aceptar la ley de Cristo el resto de los indígenas del continente, no hubiera habido nunca ocasión para que los europeos los trataran mal. Así, afirmaba en alabanza de quienes fueran sus súbditos:

Estos indios, de tan buen natural que no dieron ocasión de guerra, ni tampoco la hubo de castigo, no han tenido igual en el tratamiento, honras y libertades en todos los días, y si los demás hubieran obrado tan bien recibiendo el Santo Evangelio y bautismo sin cometer las traiciones, guerras y muertes que siempre cometieron, también lo fueran. ${ }^{99}$

Estaba tan satisfecho con las virtudes de los margariteños y con la riqueza de su tierra, especialmente cimentada en la recolección de las magníficas perlas -"alegre pítima para el corazón esta semilla", exclamaba con respecto a ellas ${ }^{100}$ - que puso punto final al aludido sexto discurso en defensa de las conquistas españolas en América con una declaración de amor tan rendida como ésta:

Pues qué se podía esperar de costelación de cielo que fue belleza de Margaritas, cría y de suelo que tal produce [-las perlas-] en todas sus costas, sino que sea la tierra más sana de todas las Indias como en efeto lo es, y los indios valientes y bien costelados, apacibles y de loable condición. ${ }^{101}$

El 22 de febrero de 1614 fue designado Juan Rodríguez de las Varillas para suceder a don Bernardo como gobernador de la Margarita, y el periodo de su gobierno concluyó oficialmente el 5 de agosto siguiente. Sin embargo, nuestro viejo conocido debió permanecer todavía en ese sitio por un tiempo, cuando menos hasta que terminara el juicio de residencia que vino a seguir acerca de su gestión un juez visitador

\footnotetext{
98 Vargas Machuca, Apologías..., Salamanca, f. 172

99 I6., f. 171v

$100 \quad$ I6., f. 177

101 I6., ff. $178 \mathrm{v}$ y 179.
} 
enviado desde Santo Domingo. Concluido éste, el simanquino resultó sentenciado a pagar una multa de 1296 pesos, para la entrega de los cuales debió verse un tanto apurado, toda vez que para entonces el Ayuntamiento de la Asunción -la villa capital de la isla le debía 2983 pesos y el tesorero de la gobernación, a su vez, 1780 reales. Pero a fin de cuentas no tuvo mayores problemas para resolver su situación, puesto que acudió en apelación ante el Consejo de Indias y consiguió que se le aceptara una finaza por 8316 reales y 22 maravedíes, designando como su fiador a Andrés Merino de Guzmán, y quedando él ya libre para emprender su regreso a España. ${ }^{102}$ Para noviembre de 1615 todavía se encontraba en la Margarita. A poco, compró en ocho mil reales una goleta -canoa, se dice en otra fuente - a su hermano Bartolomé y a bordo de ella se dirigió a Cartagena de Indias, con la intención de incorporarse a la flota que desde allí habría de salir con rumbo a la península ibérica. Noticias de 1616 lo sitúan ya en Lisboa, donde arribó solo con su navío por haberse dispersado de los demás, "viniendo del viaje de las Indias en conserva de la armada y flotas", sufriendo por ello la condena de una multa cuyo importe, tiempo después, por real ejecutoria del Consejo de Indias, debió devolvérsele. ${ }^{103}$ Para entonces, contaba con algo más de sesenta años de edad.

\section{Últimos años en Madrid}

Una vez instalado de nueva cuenta en la corte de los Habsburgo y reanudados los contactos con sus viejos amigos influyentes, don Bernardo se dedicó a procurar la impresión de algunos escritos, gran parte de los cuales seguramente ya había redactado desde América. Nunca consiguió vencer las reticencias oficiales que mo-

\footnotetext{
102. Véase el testamento hecho por Álvaro Félix de Vargas Machuca en cumplimiento de la voluntad de su padre, en Pérez Pastor, op. cit., t. II, p. 509. Luego, el Consejo de Indias ratificó la condena a Vargas Machuca por la cantidad referida. Martínez de Salinas (op. cit., p. 227) precisa que fueron 800 pesos, 2 reales, 8 maravedíes la cantidad que sentenció el juicio de residencia se debía pagar a la Caja Real.

103 Pérez Pastor, op. cit., t. II, p. 506.
} 
tivaba la edición de un tratado tan encendidamente favorable a los aventureros ultramarinos como las Apologías y discursos de las conquistas occidentales, y eso a pesar de su personal prestigio, de que lo dedicó a don Juan de Mendoza y Luna, marqués de Montesclaros, antiguo virrey en México y en Perú y para entonces consejero del rey, y de que llegó a contar con el visto bueno para la edición del fraile agustino Manuel de Villegas Peralta, quien firmó un dictamen favorable al respecto en el convento madrileño de San Felipe el 20 de julio de 1618. En cambio, sí pudo ver cómo en 1619 salía de la imprenta que Diego Flamenco tenía en Madrid otro trabajo suyo, dedicado a temas de equitación y dirigido al conde de Villaflor, don Luis Enríquez, intitulado Teórica y exercicios de la gineta, primores, secretos y advertencias della, con las señales y enfrenamientos de los cavallos, su curación y beneficio, el cual venía a ser una segunda edición, "corregida y aumentada", del Libro de exercicios... aparecido desde 1600. Dos años después, en 1621, apareció en el propio Madrid un último texto suyo, el folleto Compendio y doctrina nueva de la gineta, dedicado a Felipe IV, que es un interesante complemento a los dos anteriores referentes a esa manera específica de andar a caballo.

Estos últimos años de su existencia, a raíz de su vuelta a Indias, los pasó Vargas instalado en la villa de Madrid. El 20 de mayo de 1621, mes y medio después de la muerte de Felipe III, y cuando con motivo de la entrada en el gobierno de su hijo y sucesor todo estaba cambiando en la corte, recibió el experimentado capitán el título que lo hacía gobernador de las provincias neogrnadinas de Antioquia, Cáceres y Zaragoza, con sueldo de dos mil ducados anuales. El 14 de junio inmediato rindió el correspondiente pleito homenaje ante el Consejo Real, entrando así oficialmente en el desempeño de su cargo, el cual debería tener una duración de cinco años. Este nuevo puesto que se le encomendaba era el más importante de los que había ocupado, ya que la referida gobernación se extendía sobre un territorio amplio, fértil y de abundante riqueza aurífera. ${ }^{104}$ Pero el veterano guerrero y autor, que debía andar ya por los sesenta y seis años, estaba seguramente ya un tanto viejo y achacoso. Aunque enseguida empezó con 
los preparativos para la larga excursión hacia su nuevo destino, éstos no caminaron muy rápidamente. Necesitaba dinero para el viaje, y con el objeto de obtenerlo, a cuenta de sus salarios de gobernador, durante el mes de mayo otorgó poder a Álvaro de Herbías Calderón para que le consiguiera quinientos ducados, ofreciendo en hipoteca el patrimonio familiar de Simancas. En 18 de junio recibió 375 ducados que le prestó el capitán Simón Fres, el 22 de noviembre otros mil por parte de Pedro Vergel, "vecino de Sevilla", y el 25 de enero de 1622 trescientos más de Francisco Alderete. ${ }^{105}$ Muy agradecido por aquel favor que le hiciera el referido Vergel, seguramente que al recibir el dinero que éste le proporcionara no se acordó mucho de que, según el maldiciente de su amigo el de Villamediana, buena parte de la fortuna de ese alguacil de corte tenía un origen conyugal no demasiado honroso. Recuérdense los maravillosos pero terribles versos que dedicó don Juan de Tassis al dicho Pedro Vergel en ocasión de una actuación suya en la plaza de toros, cuando

\author{
Muy galán salió Vergel \\ con cintillo de diamantes; \\ diamantes que fueron antes \\ de amantes de su mujer,
}

en circunstancia en que el astado que se corría no quiso acudir al cite que le hacía el caballero, puesto que

El toro tuvo razón en no osar acometer, pues mal pudo él oponer dos cuernos contra un millón.

A pesar de todo lo cual, a lo que decía el propio poeta, no le fue

\footnotetext{
104 Otero D'Costa, op. cit., p. 76.

105 I6., p. 77. Los documentos referentes a estas deudas de Vargas Machuca, así como a otras que tuvo y a otras más que a él debían pagársele, pueden verse en Pérez Pastor, op. cit., pp. 505 a 510.
} 
a fin de cuentas nada mal al rejonero:

\author{
En ocasión oportuna \\ anduviste, Vergel, hombre, \\ y colocaste tu nombre \\ en los cuernos de la luna. ${ }^{106}$
}

A principios de 1622 se agravaron los males del gobernador $y$, ya muy malo, el 16 de febrero de ese año hizo llamar al notario Fernando de Villanueva para dictarle su postrera voluntad. No tuvo tiempo de hacer con demasiado detalle el testamento, cuyo cabal cumplimiento y complementaciones necesarias encomendó a su hijo Álvaro Félix. A lo que parece, no era mucho lo que dejaba a sus herederos, si no eran unas cuantas sumas que se le debían, aparte de una notable hoja de acciones cumplida en provecho de su patria y de su rey,

por tiempo de más de cincuenta y dos años en muchos y muy señalados servicios con grandes gastos de mi hacienda y de la de don Juan y don Álvaro Félix, mis hijos, por cuya causa los dejo muy pobres: y ansí suplico humildemente a su Majestad y señores de su Real Consejo se sirvan de honrar y hacer merced a los dichos mis hijos, por mis herederos. ${ }^{107}$

106 En José María de Cossío, Los toros. Tratado técnico e histórico, 11 tt., Madrid, EspasaCalpe, 1943 y ss., t. II, pp. 379 y 380 . Claro que no puede haber la certeza absoluta de que los dos Pedros Vergel, el rico prestamista y el cornudo toreador fueran la misma persona. Pero presentes ambos en la misma época y dentro del mismo ambiente, parece que hay suficientes indicios para sospechar su identidad. A lo mejor, lo que movió al conde a componer sus bárbaras sátiras fue, precisamente, algún pleito con Vergel debido a un préstamo que le hubiera solicitado el enorme pródigo que él era. Martínez de Salinas (op. cit., p. 231), por su parte, precisa que el Vergel que hizo el préstamo estaba ligado con el tráfico de la Margarita. Juan Manuel Rozas, por su parte, en la edición de las Obras de Villamediana (Madrid, Castalia, 2001; Biblioteca Clásica Castalia, 66), p. 274, explica cómo Pedro Vergel, madrileño venido al mundo en 1580 , de familia de origen francés, alguacil de corte y célebre jinete, fue "la persona más veces satirizada por el Conde", pero que también mereció la defensa y el elogio de Lope de Vega, que le dedicó una obra llamada nada menos que El mejor mozo de España; allí, Rozas alude al trabajo de Alejandro Martín Ortega, Pedro Vergel (Madrid, 1965), la cual no he podido consultar.
C
A L $E$
D
S
C
O P I
$\mathrm{O}$ 
Testó, pues, el 16 de febrero, cuando ya no tenía ni siquiera fuerzas para firmar sus últimas voluntades, y murió el día siguiente, 17. Según la partida de su defunción, por entonces vivía junto a la casa de los religiosos premostratenses, en compañía de su referido hijo Álvaro y parece que también de una prima suya, Isabel Ruiz Lanchero o Lancher, viuda de Fulgencio Meneses, que fueron quienes quedaron como sus testamentarios y albaceas. Sus dos hijas, Bernardina y María, se hallaban recluidas en el Convento de la Concepción de Panamá, donde habían profesado como religiosas; el otro vástago varón, Juan, se hallaría con toda certeza en alguna ocasión de servicio al rey. ${ }^{108}$ En cuanto a su segunda esposa, Juana Mojica, es muy probable que hubiera muerto tiempo atrás, puesto que no hay noticias de ella posteriores a la primera estancia indiana de su marido. Sus escasos haberes los dejó, "por iguales partes con la bendición de Dios e con la mía" a sus hijos Juan y Álvaro; para el sustento de las dos mujeres dejaba establecido un censo de mil pesos con los cuales, a la muerte de ellas, habría de fundarse una capellanía de misas en el mismo convento en que estaban. ${ }^{109}$ La primogenitura, con todos sus privilegios simbólicos, pasó por supuesto a Juan; declaraba Álvaro Félix, al testar en nombre de su padre, como éste había sido

el mayor hijo que quedó del dicho capitán Juan de Vargas, y como tal le pertenecían todos los papeles de servicios que quedaron del dicho su padre y la executoria original que tenía, en cuyo derecho sucede Don Juan de Vargas, hijo mayor que quedó del dicho Don Bernardo de Vargas, su padre, y ansí mando se cobren de la persona o personas en cuyo poder estuvieren por quanto pertenecen al dicho Don Juan. ${ }^{110}$

107 Pérez Pastor, op. cit., t. II, pp. 507 y 508.

108 Este hijo mayor suyo, Juan, llamado así con toda seguridad en memoria de su abuelo el funcionario de Simancas, llegó también a ostentar grado de capitán. Militó sobre todo en Cumaná, y en 2 de agosto de 1629 firmó un memorial de 6 hojas sobre los "Servicios del capitán don Juan de Vargas Machuca, y del gobernador don Bernardo de Vargas Machuca, su padre", el cual apunta José T. Medina (op. cit., t. II, p. 314) que se encuentra en el Archivo General de Indias, donde por cierto lo vio María Luisa Martínez de Salinas (op. cit., p. 224, nota 138) en el legajo 85, ramo 2 correspondiente a la Audiencia de Santo Domingo.

Pérez Pastor, op. cit., t. II, pp. 507 y 508. 
Según sus postreras instrucciones, el viejo capitán fue enterrado muy cerca de su vivienda, en la iglesia de San Norberto. ${ }^{111}$

Eran entonces, como se ha visto, los primeros meses del reinado del postrer Felipe de Austria, en cuya corte de mecenas, en la "Academia de Palacio", como intelectual, hubiera tenido quizás buena acogida, al lado de la flor y nata de los últimos representantes del mayor siglo español, en torno de la genial figura de Francisco de Quevedo y Villegas. Dentro de ella tuvo por breves días relevancia central su gran amigo don Juan de Tassis y Peralta, el legendario conde de Villamediana que, ese mismo año, el 21 de agosto, iba a ser muerto por "impulso soberano", según se aseguró en voz baja, en venganza de sus supuestas relaciones con la joven esposa del monarca.

*

110 Ib., t. II, p. 509.

111 El registro de su muerte está en el libro $2^{\circ}$. de difuntos de la parroquia de San Martín, y se encuentra transcrito en Ib., t. I, pp. 590-593, en las "Noticias de la vida y obras del capitán D. Bernardo de Vargas Machuca" (en Vargas Machuca, Milicia..., 1892, v. I, pp. V-XIV), p. XII y en Otero D'Costa, op. cit., p. 77. Este es su texto:

1622.- Febrero 17.- Don Bernardo de Vargas Machuca. Capitán general de su Majestad en las Indias, murió este día, recibió los Santos Sacramentos, hizo testamento ante Fernando Villanueva, Escribano. Por él se mandó enterrar en San Norberto, y mandó que el funeral y misas que por su alma se hicieren sea de voluntad de sus testamentarios, que son: su hijo Dn. Álvaro Félix Muxica, y Doña Isabel Ruiz Lanchero, su prima; viven junto a los Premostratenses.

Por cierto que en algunas de las copias de esa partida el apellido de la prima Isabel se anota como "Ruiz Sánchez".

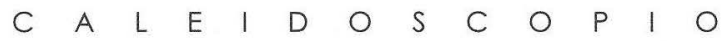


